\title{
A typology of circular start-ups: An Analysis of 128 circular business models
}

\author{
Marvin Henry*, Thomas Bauwens, Marko Hekkert, Julian Kirchherr \\ Innovation Studies Group, Copernicus Institute of Sustainable Development, Utrecht University, the Netherlands
}

\section{A R T I C L E I N F O}

\section{Article history:}

Received 14 May 2019

Received in revised form

26 August 2019

Accepted 20 September 2019

Available online 26 September 2019

Handling Editor: Cecilia Maria Villas Bôas de Almeida

\section{Keywords:}

Circular economy

business model innovation

sustainable development

start-up

circular business models

nature-based solutions
The circular economy (CE) concept is much-heralded among policy-makers, scholars and industry professionals as an accelerated pathway towards sustainability. This move away from the dominant linear system where products are discarded at the end of product lifecycle is deemed necessary since it is the main cause of an accelerated resource consumption. Business models are considered as a key enabler for the shift from a linear to a CE. However, research on circular business models has mainly focused on circular approaches adopted by incumbent firms, while the contributions of newly established firms (the authors call these 'circular start-ups') have been largely overlooked. This article scrutinises the business models of circular start-ups and how they may differ from those of incumbent firms embracing CE. For this, it analyses the circular business model strategies and innovations adopted by circular start-ups, relying on a novel data sample of 128 circular start-ups identified in three major CE ecosystems in Europe: the Randstad region in the Netherlands, Berlin and London. Based on this data, a novel typology of circular start-ups is proposed, distinguishing between five circular start-up archetypes: design-based, waste-based, platform-based, service-based and nature-based start-ups. The results also show that circular start-ups tend to embrace strategies corresponding to higher levels of circularity than those of incumbents. This preliminarily suggests that circular start-ups can indeed make major contributions to transitioning towards $\mathrm{CE}$.

๑) 2019 Elsevier Ltd. All rights reserved.

\section{Introduction}

Moving away from 'business as usual' appears to be necessary to break with the current trends of resource use casued by a linear socioeconomic system. Extraction of fossil fuels, ores, minerals and biomass rose 12 -fold during the 20th century, amounting to 84.4 billion tonnes in 2015, with further doubling expected until 2050 (Circle Economy, 2019; Krausmann et al., 2009). This accelerating material use caused by product discard at the end of the product lifecycle poses serious threats to the sustainability of society. A circular economy (CE) proposes a shift from this model to one in which materials are circulated in closed-loop production systems to reduce resource depletion and eliminate waste (Ellen MacArthur Foundation, 2012; Geng et al., 2009; Murray et al., 2017). There are many competing CE definitions (Kirchherr et al., 2017). The authors define a CE throughout this paper as 'an economic system that is

\footnotetext{
* Corresponding author. Innovation Studies Group, Copernicus Institute of Sustainable Development, Utrecht University, Princetonlaan 8a, 3584 CB Utrecht, the Netherlands.

E-mail address: m.henry@uu.nl (M. Henry).
}

based on business models which replace the "end-of-life" concept with reducing, alternatively reusing, recycling and recovering materials in production/distribution and consumption processes, thus operating at the micro-level (products, companies, consumers), meso level (eco-industrial parks) and macro level (city, region, nation and beyond), with the aim to accomplish sustainable development, which implies creating environmental quality, economic prosperity and social equity, to the benefit of current and future generations' (Kirchherr et al., 2017, pp. 224-225).

CE has become a widely discussed topic among policy-makers, scholars and industry professionals alike (Urbinati et al., 2017). Despite these numerous discussions, the implementation of $\mathrm{CE}$ remains extremely limited. For instance, a study showed that in 2005 , only $6 \%$ of waste materials were recycled at the global level, with the remainder were incinerated, landfilled, or dispersed into the environment (Haas et al., 2005); a recent report supports this argument stating that the world is only 9\% circular today (Circle Economy, 2019). While governments have been argued to hold pivotal roles in building a vision and steering market actors towards a CE and also academics may play a role in furthering the transition towards a CE (Kirchherr and Piscicelli, 2019), the role that the private sector can play has been particularly highlighted in recent 
years (Accenture, 2014; Lieder and Rashid, 2016; Lüdeke-Freund et al., 2018; Urbinati et al., 2017; Antikainen et al., 2017). Indeed, changes in business models are considered by many scholars as a key enabler for the shift from a linear to a CE (van Renswoude et al., 2015; Ellen MacArthur Foundation, 2012; McKinsey and Co. 2015; Ghisellini et al., 2016; Bocken et al., 2016; Lewandowski, 2016).

In principle, $\mathrm{CE}$ pioneers can be start-ups as well as incumbents - the drive towards CE is mainly determined by the respective organisations' circular spirits and entrepreneurial capabilities (De los Rios and Charnley, 2017). However, a common view in innovation research is that incumbents are seldom the source of innovations that break with existing dominant designs because they are locked into previous investments, existing supply chains and business models that are hard to adapt once fully developed (Christensen, 1997; Henderson and Clark, 1990; Hill, Rothaermel, 2003; Johnson, 2010). Similarly, it has been questioned whether incumbents will or can fully embrace the more 'radical' business model approaches to CE, such as sharing platforms (e.g. peer-topeer) or product-service systems (PSS; Lieder and Rashid, 2016). Empirical evidence indicates that large incumbents tend to focus on widespread strategies like recycling, which do not necessitate shifting their core business models (Bocken et al., 2017; Stewart and Niero, 2018). In contrast, start-ups, as new market entrants, have been argued to have a higher capacity to adopt more disruptive circular business models (CBMs; defined in section 2), due to their higher flexibility and responsivity to market changes (Bergset, Fichter, 2015; Bos-Brouwers, 2009; Hockerts and Wüstenhagen, 2010; Rizos et al., 2016). Entrepreneurship has been recognized as a major conduit for sustainable products and processes, and new ventures are being held up as an answer to many social and environmental concerns (Hall et al., 2010).

The present article aims to shed further light on the CBM strategies and circular innovations pursued by circular start-ups (CSUs) to contribute to the theoretical body of sustainable innovations and to existing frameworks operationalizing CBMs. It is one of the few large-N studies on circular economy (Kirchherr and van Santen 2019). Thus far, research on CBMs has mainly focussed on approaches to CE by large incumbents, such as Google, Carlsberg, Renault or Unilever, possibly because of their higher visibility and the influence they have on their respective markets (Bocken et al., 2017; Franco, 2017; Frishammar and Parida, 2019; Ma et al., 2014; McIntyre, Ortiz, 2016; Niero et al., 2017; Stewart, Niero, 2018; Urbinati et al., 2017; Williams, 2007). In contrast, to the best of the authors' knowledge, no empirical scholarly work thus far has been carried out on CSUs directly. In this research circular start-ups (CSUs) are defined as new, independent and active companies pursuing a CBM (further detailed in section 2). Circular entrepreneurship is still a quite novel concept in scientific literature (Zucchella and Urban, 2019).

Therefore, the objective of this research is to build on existing literature on circularity strategies and circular (sustainable) business model innovation to develop a business model typology of the potentially most innovative players in private sector $\mathrm{CE}$. The questions addressed by this paper are as follows:

RQ1: Which CBM strategies are adopted by CSUs?

RQ2: What types of CBM innovations do CSUs pursue?

The authors address these questions by analysing the CBM strategies and innovations of 128 CSUs $^{1}$ located in three major CSU ecosystems in Europe, i.e. the Randstad region in the Netherlands, ${ }^{2}$ London and Berlin. The dataset was newly compiled and evaluated for the purpose of this study and has not been used for any other

\footnotetext{
1 The full list of start-ups scrutinized in this study can be found in the Appendix.

2 The Randstad region comprises Amsterdam, Rotterdam, Utrecht and The Hague.
}

peer-reviewed publications before, and to the best of the authors knowledge there has been no research conducted on CSUs' actual business models. Therefore, the data can be proclaimed as novel. Relying on this empirical analysis, a novel typology of CSUs is proposed, distinguishing between five business models: designbased start-ups, waste-based start-ups, platform-based start-ups, service-based start-ups and nature-based start-ups. In addition, when comparing CBM strategies, the findings show that CSUs across all types tend to embrace activities corresponding to a higher level of circularity than incumbents.

The CSU typology based on a representative data sample shown in this paper is a step towards better understanding the role of entrepreneurship in circularity and sustainability transitions. The envisaged findings based on extensive empirical analysis are of value to foster a link between scientific and practical approaches to CE and will contribute to deepen the insight on business models of CSUs. The abovementioned typology and CSU archetypes will help to guide a future scientific agenda through expounding and highlighting their business models and thereby inspiriting and enabling more systematic research on CSUs (i.e. the actual business models developed by circular entrepreneurs). For firms interested in $\mathrm{CE}$, applicable combinations of CBM strategies and respective CBM innovation paths are elucidated, which will serve as an important source of information and inspiration on business model approaches towards CE. At the same time, by highlighting the characteristics, especially of those CSUs that have achieved high levels of circularity, lessons can be drawn for managers willing to increase the level of circularity of their businesses. Managers could, for instance, examine CSUs' activities to identify promising opportunities both within and between industries, and adopt best practices in their own business models. The findings are also relevant to policy-makers who intend to support circular (start-up) activity and circular innovation in the area under their administrations.

The remainder of this paper is structured as follows: a literature review on sustainable and CBMs and the conceptual framework underpinning this investigation are presented in section 2 , the methodology is presented in section 3, the empirical analysis and the discussion of the results are shown in section 4, and concluding remarks about their policy and management implications are provided in section 5 .

\section{Literature}

\subsection{Literature review}

This section outlines how sustainable and circular business models, innovations and strategies have been defined in existing research and succinctly reviews the extant literature on the relevant concepts of environmental or sustainable entrepreneurship. In line with previous developments of the business model literature (Beattie and Smith, 2013; Osterwalder et al., 2010, 2005; Richardson, 2008), Bocken et al. (2014) highlight three main elements composing sustainable business models: the value proposition (i.e. the offer and the target customer segments), the value creation and delivery (i.e. the activities, resources, partners and distribution channels), and the value capture (i.e. the cost structure and the revenue model). Accordingly, a sustainable business model (SBM), when appropriately designed, should create, deliver, and capture economic value while simultaneously contributing to environmental and/or social sustainability (Boons and LüdekeFreund, 2013; Lüdeke-Freund et al., 2018; Schaltegger et al., 2016).

CBMs incorporate CE principles as guidelines for business model design (Heyes et al., 2018; Pieroni et al., 2019). They can be defined as circular operations on the micro-level that aim at fully closing product or material loops and thereby making the 'end-of-life' 
concept obsolete or keeping resources in use for as long as possible through reducing, alternatively reusing, recycling or recovering them (Kirchherr et al., 2017; Linder and Williander, 2017). Circular is a more concrete term than sustainable, since it describes a way to achieve (some form of) sustainability (Geissdoerfer et al., 2017). Indeed, while the concept of SBM is centred around the finality of creating economic, environmental and social value without prescribing specific directions for achieving it (Lüdeke-Freund and Dembek, 2017; Stubbs, Cocklin, 2008), CBMs are more narrowly framed and establish specific ways to address the negative consequences of business operations leading to excessive waste generation and resource depletion.

The overlap of CBMs with SBMs may lead some authors to see the former as a subset of the latter (e.g. Bocken et al., 2014; LüdekeFreund et al., 2018). However, the authors of this paper disagree because, as noted by Pieroni et al. (2019), SBMs can also generate unsustainable effects if design options for CE are only partially in place (e.g. encouraging over-consumption or fast replacement when the respective reverse-logistics processes are not in place). Furthermore, while SBMs hold social relevance or work enrichment as a driver for value creation on top of environmental and economic impacts, these aspects have been described as secondary benefits instead of core drivers for value creation in the case of CBMs (Pieroni et al., 2019).

Closely related streams of literature have developed around sustainability-oriented innovations (Adams et al., 2016; Klewitz and Hansen, 2014; Schiederig et al., 2012) and, in particular, SBM and CBM innovations (Geissdoerfer et al., 2018). SBM innovations incorporate sustainability principles into the business model innovation process (Foss and Saebi, 2016; Massa and Tucci, 2014), seeking to conceptualise and implement new business models while also benefitting society and the environment (Boons and Lüdeke-Freund, 2013; Lüdeke-Freund et al., 2018; Pieroni et al., 2019). CBM innovations seek to create CBMs by integrating the more concrete circularity principles into the business model innovation process (Diaz Lopez et al., 2019; Geissdoerfer et al., 2018; Linder and Williander, 2017). An emblematic example of CBM innovations is the product-service system model, which entails a conversion from selling a product to providing leasing and sharing services, thereby decoupling the service provision from the ownership of physical goods (Tukker, 2004; Tukker and Tischner, 2006; Vezzoli et al., 2015). This model financially incentivizes the company to invest in the durability and reuse of products and materials (Baines et al., 2007; Mont and Tukker, 2006; Williams, 2007).

CBM innovations can occur at different positions along the value chain of goods and services. Urbinati et al.'s (2017) approach (adjusted version further discussed in Section 2.1.) distinguishes between upstream, downstream and full business model adoptions for circularity:

- Downstream circular companies adopt circular innovations related to their revenue model and customer interfaces, but they do not necessarily make relevant changes at the supplier level and at internal practices or product design;

- Upstream circular companies are classified as adopting circular innovations internally, and with a focus on interaction with their suppliers. Thus, they concern innovations during the pre-usage or pre-customer face of a product or service. This can happen through design practices (e.g. design for recycling/reuse/disassembly (Jawahir et al., 2007), source material innovation) the collaboration with suppliers to utilize external waste streams, or by selecting partners which can provide biodegradable materials;
- Full circular companies are those which adopt both upstream and downstream CBM innovations.

In addition, $\mathrm{CBM}$ innovations should be distinguished from CBM strategies, which can be viewed as firms' general approach towards CE. That is, CBM innovations are the processes by which firms practically implement their CBM strategies. Several conceptualisations of CBM strategies exist (e.g. Bocken et al., 2016; Linder, Williander 2017; Ünal and Shao, 2019; Urbinati et al., 2017, Whalen, 2017). Among those, the so-called R-framework distinguishes between different strategies to embrace circularity, known as R-strategies. Literature and practice offer different versions of the R-frameworks (Blomsma and Brennan, 2017; Sihvonen and Ritola, 2015; Yan and Wu, 2011), ranging from the 3 Rs (reduce, reuse, recycle) - in the Chinese government policy on CE (Geng et al., 2009; PRC, 2008) - to 10 Rs in a more recent literature review by Reike et al. (2018). While the number of Rs differ from list to list, most of the R-lists establish a priority order for approaches to circularity, with the first $\mathrm{R}$ viewed to be a priority to the second $\mathrm{R}$ and so on. These R-strategies can be developed within the two types of material cycles characterising the CE (Ellen MacArthur Foundation, 2012; McDonough, Braungart, 2002): the biological cycle, which encompasses the flows of food and biologically-based materials (e.g. cotton, wood) that are designed to return back to the biosphere through processes like composting or anaerobic digestion, and the technical cycle, which relates to the flows of inorganic or synthetic materials. The 4R-framework, which is the most commonly used $\mathrm{R}$ framework in the $\mathrm{CE}$ literature according to Kirchherr et al. (2017), will be used throughout this paper (see section 2.1. for further details).

Adopting SBMs and CBMs and corresponding innovations and strategies is often seen first in new entrants, such as start-ups, due to their higher flexibility and their capacity to stimulate disruptive sustainability innovation (Cohen and Winn, 2007; Dean and McMullen, 2007; Hall et al., 2010; Hockerts and Wüstenhagen, 2010). Start-ups can be defined as 'new' (i.e. typically operating for four to six years) and 'independent' entrepreneurial ventures designed to effectively develop and validate a scalable, repeatable and at least break-even business model (Brush and Vanderwerf, 1992; Klyver and Terjesen, 2007; Luger and Koo, 2005; Rabideau et al., 2016; Robehmed, 2013; Zahra et al., 2000). The literature on innovation and entrepreneurship typically views incumbents in a stronger path dependency than start-ups (Christensen, 1997). Indeed, once the business model is established, it is typically highly difficult for a company to change it. As Chesbrough (2010) argues, companies may invest extensively in the development of new products and technologies that will be commercialized through their business model, but they often have little if any ability to innovate the business models through which these inputs will pass. Empirical evidence indicates that large incumbents tend to focus on lower CBM strategies, like recycling, and make changes at the margin instead of shifting their core business models (Bocken et al., 2016; Stewart, Niero, 2018).

By contrast, start-ups, as new market entrants, can adopt CBMs from the start, take a holistic perspective at their business model and monetize design-to-last and maintenance efforts. In addition, they are not exposed to the risk of cannibalizing the market share of their prior products or devaluating previous investment in manufacturing processes (Hockerts and Wüstenhagen, 2010). Furthermore, typical limitations to the implementation of CBMs like company environmental culture, technical know-how, or administrative burden - only partly apply to start-ups. For the latter, more horizontal management styles, decreased bureaucratic structures and more informal communication channels lead to higher flexibility and responsivity to changing market 


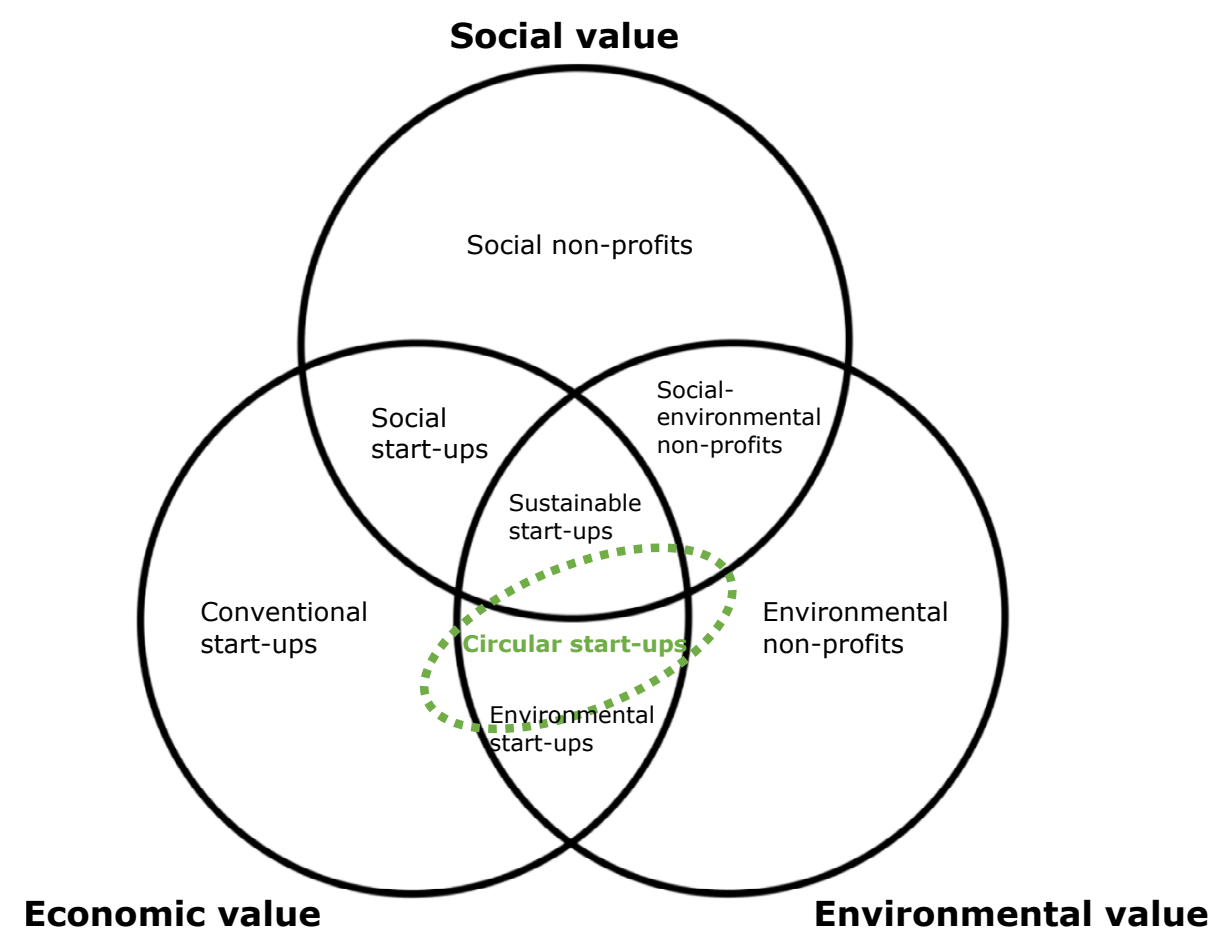

Fig. 1. The relationships of circular start-ups with other types of enterprises.

circumstances (Bos-Brouwers, 2009; Hockerts, Wüstenhagen, 2010; Rizos et al., 2016; Schaltegger et al., 2016).

Various streams of research have looked at the relationship between different aspects of sustainability and start-ups or entrepreneurship, including environmental entrepreneurship or ecopreneurship (Lenox and York, 2011; Schaltegger, 2002), social entrepreneurship (Borzaga and Defourny, 2001; Doherty et al., 2014) and sustainable entrepreneurship (Choi and Gray, 2008; Cohen and Winn, 2007). While environmental entrepreneurship exclusively focuses on the simultaneous creation of economic and environmental value (Jiang et al., 2018) by addressing environmentally relevant market failures, social entrepreneurship seeks to achieve social goals (e.g. work enrichment, ethical sourcing) and to secure funding for it. Sustainable entrepreneurship aims to embrace sustainability more comprehensively across a "triple bottom line" perspective, integrating its economic, environmental and social dimensions (Schaltegger and Wagner, 2011; Thompson et al., 2011). The specificity of CSUs is that they have adopted a CBM.

The relationships between CSUs and closely related types of ventures are illustrated in the Venn diagram below (see Fig. 1). CSUs have a large overlap with environmental start-ups ${ }^{3}$ and environmental entrepreneurship, as both types of organisations simultaneously pursue the creation of economic and environmental value. However, CSUs are more specific in their operationalization, focusing on closing product or material loops, while environmental start-ups include a broader range of business models, for example renewable energy generation or biodiversity protection. Moreover, CSUs partly overlap with sustainable start-ups when, on the top of economic and environmental value, they also generate value to social relevance or work enrichment as secondary effects. This distinguishes them from social start-ups (e.g. fair trade

\footnotetext{
3 The terms "green start-up" or "clean-tech start-up" are also used in the literature as synonyms for environmental start-up (Bergset, 2017; Bergset, Fichter,
} 2015; Colombelli, Quatraro, 2019). organisations, work integration social enterprises), for which this aspect is the essential driver for value creation. CSUs may overlap with conventional start-ups when the implementation of CBM strategies and innovations are only partial and lead to the creation of economic value, but not environmental or social value as a primary focus. Finally, CSUs can be for-profit (i.e. their main goal is to maximize economic value for those who control them), not-forprofit (i.e. there is limited creation of economic value for controlling stakeholders) or non-profit (i.e. the economic value is entirely retained by the organization for the fulfilment of its social and/or environmental missions). ${ }^{4}$ For this reason, CSUs partly overlap with (social or environmental) non-profits.

Within the literature on environmental and sustainable entrepreneurship, which are the concepts closest to CSUs, there is a dearth of research on the actual business models developed by sustainable entrepreneurs, that is, what entrepreneurs practically do to achieve (environmental) sustainability. Instead, several studies have focused on defining the concepts (Schaltegger Wagner, 2011; Shepherd, Patzelt, 2011) and on understanding the entrepreneurial opportunities and challenges arising from the existence of externalities and market inefficiencies (Cohen, Winn, 2007; Dean, McMullen, 2007; Jiang et al., 2018; Pacheco et al., 2010; York, Venkataraman, 2010). Other studies have explored the relationships between different actors (e.g. start-ups and incumbents; Hockerts, Wüstenhagen, 2010; Schaltegger et al., 2016) or strategic issues, such as the entrepreneurship process (Belz, Binder, 2017; Keskin et al., 2013) or the potential necessity of sustainable entrepreneurs to engage in institutional work to achieve their goals (Pinkse, Groot, 2015; Thompson et al., 2015). A research stream has looked at the skill sets and motivations of sustainable entrepreneurs and how they differ from those of conventional entrepreneurs (Kirkwood, Walton, 2010; Nhemachena, Murimbika,

\footnotetext{
${ }^{4}$ For definitions of "for-profit", "not-for-profit" and "non-profit", see for instance Defourny, Nyssens (2010).
} 
Table 1

Coding categories for RQ1.

\begin{tabular}{|c|c|}
\hline $\begin{array}{l}\text { CBM } \\
\text { strategy }\end{array}$ & Definition \\
\hline Regenerate & $\begin{array}{l}\text { Maintain and increase the delivery of biological ecosystem services (i.e. the benefits provided) to society, for instance through urban agriculture, green roofs } \\
\text { or aquaponics }\end{array}$ \\
\hline Reduce & $\begin{array}{l}\text { Increase efficiency of product design or manufacturing by preventing or minimising the use of specific hazardous materials or any virgin materials, or } \\
\text { allowing for more intensive product use }\end{array}$ \\
\hline Reuse & Bring products back into the economy after initial use, or extend the lifespan of products and their parts (through repair, second-hand markets etc.) \\
\hline Recycle & Process materials through, e.g., shredding or melting to obtain the same (upcycling) or lower (downcycling) quality \\
\hline Recover & Incinerate residual flows with recovery of embodied energy \\
\hline
\end{tabular}


Reike et al. (2018).

\section{8; Parrish, 2010).}

Similarly, while research on sustainable or circular innovations and strategies often cites entrepreneurship as a major conduit for these, it has rarely focused on the business models specifically developed by new entrants or start-ups (Boons, Lüdeke-Freund, 2013; Klewitz, Hansen, 2014). For instance, Geissdoerfer et al. (2018) mention sustainable start-ups as a way to develop SBM innovations without discussing it further. Several recent studies present taxonomies or typologies of circular strategies and innovations adopted by firms, but do not distinguish between incumbents and new entrants (Lüdeke-Freund et al., 2018; Ünal, Shao, 2019). The typology of CSUs presented in the current paper seeks to address this research gap.

\subsection{Theoretical framework}

This section presents the theoretical framework that was developed to code the empirical data collected for this paper, based on the literature just outlined. RQ1 is concerned with the CBM strategies adopted by CSUs. To code these, the 4R-framework as presented by Kirchherr et al. (2017) was chosen over the other versions of the $\mathrm{R}$-framework, because the former has been used more frequently in previous literature than the latter (Kirchherr et al., 2017; Stewart, Niero, 2018). Therefore, this analysis is easier to compare with existing studies like Stewart and Niero's analysis of incumbents' approaches to circularity (2018).

The hierarchy among the R-strategies in the 4R-framework corresponds to different degrees of resource value retention, with higher strategies corresponding to higher value retention. The retention of resource value here means "conservation of resources closest to their original state, and in the case of finished goods retaining their state or reusing them with a minimum of entropy as to be able to give them consecutive lives" (Reike et al., 2018, p. 254). Hence, activities that explicitly deal with the resource streams after product usage (Recover, Recycle) are ranked lowest, because they tend to lose any of the original product structure and, therefore, correspond to low value retention. In addition, recycling materials often requires high energy inputs for collection and re-processing, which may supersede the retained value (Ghisellini et al., 2016; Reike et al., 2018). Recycling and energy recovery are also typically easier to implement than other strategies, since they require little changes to the fundamentals of the business model (Ranta et al., 2018) and are, therefore, still largely compatible with a linear economy (Potting et al., 2017). Following this logic, Reuse, which is aimed at extending the use phase of products, is ranked higher than Recycle and Recover, because products are generally used again for the same purpose for which they were conceived, thereby retaining most of the resource value (Castellani et al., 2015). However, it is not considered as desirable as Reduce, where potential residual resource streams are avoided before the product even gets in circulation.
A dimension that has not been well covered so far by the existing versions of the R-frameworks is the preservation and enhancement of natural/biological ecosystems to deliver products or services. This dimension is important to consider as far as CSUs are concerned, because some of them are engaged in the development of so-called 'nature-based solutions', which is a structural cluster resulting from the dataset (see section 4.3.5) and is a widely discussed topic in theory and policy (Davies, Lafortezza, 2019; European Commission, 2015; Faivre et al., 2017; Frantzeskaki, 2019; Kabisch et al., 2016). These companies use ecosystems with decreased input of non-renewable natural capital and increased investment in renewable natural processes (Maes, Jacob, 2017). Thus, beyond the existing 4R-framework, the CBM strategy Regenerate was inductively included to cover CSUs engaged in the development of solutions based on natural/biological ecosystems. This strategy was placed above Reduce because Regenerate seeks not only to use less resources in production and consumption processes, but also to restore natural or modified ecosystems, thereby not only retaining resource value, but also increasing it. The authors summarise the different $\mathrm{R}$ strategies relevant for this paper in Table 1.

Looking at CBM strategies through the frameworks presented in Table 1 gives insight about the respective organisations' CBM strategies (i.e. their general approach towards CE) but is not informative about the types of CBM innovations they pursue. ${ }^{5}$ In order to address this, and to gain insight into the modes of adoption of the CBM strategies, the authors added CSUs' innovation types to the analysis. The CBM innovations developed by CSUs were coded based on their positions along the value chain (supplier or customer) and on their organisational focus (external or internal; see Table 2). Adjusting the taxonomy of CBMs proposed by Urbinati et al. (2017), the authors introduced the additional 'source' category to differentiate, within upstream activities - those conducted by the focal organisation internally (source) and those conducted in interaction with suppliers and partners (upstream). It can be argued, that - due to their collaborative nature - especially the upstream-oriented innovations require a strong business network and high social capital, which are fostered and crosscutting relationships as a communal base for cooperation and collective action (Nahapiet, Ghoshal, 1998; Peng et al., 2018). Thus, early-on effort on (strategic and public) relationship-building activities to build up social capital is highly relevant for CSUs to enable upstream circular innovations (Paunescu and Raluca Badea, 2014; Saffer, 2019).

This differentiation in source and upstream is deemed necessary especially on the backdrop of innovation ecosystem and systems

\footnotetext{
5 The innovation types were not compared to incumbents' innovation types because the authors newly developed the innovation type framework wherefore there existed no comparative studies.
} 
Table 2

Coding categories for RQ2: CBM Innovation types.

\begin{tabular}{|c|c|c|c|}
\hline Key actor & CBM Innovation Category & CBM Innovation Type & Description \\
\hline \multirow[t]{4}{*}{$\begin{array}{l}\text { Downstream } \\
\text { (consumers) }\end{array}$} & $\begin{array}{l}\text { PSS (servitisation/no } \\
\text { customer ownership) }\end{array}$ & $\begin{array}{l}\text { Use phase-oriented } \\
\text { Result/performance- } \\
\text { oriented }\end{array}$ & $\begin{array}{l}\text { Improved usage efficiency through renting, leasing, sharing, extended after-sales services } \\
\text { Improved usage efficiency through subscription-based business models or pay-per-use, i.e. } \\
\text { focusing on the functionality }\end{array}$ \\
\hline & $\begin{array}{l}\text { Active consumer } \\
\text { involvement }\end{array}$ & Return, repair, reuse & $\begin{array}{l}\text { Inclusion of consumers in after-use product/resource lifecycle; enabled by value recovery } \\
\text { and take-back processes at the source }\end{array}$ \\
\hline & & Collaborative consumption & $\begin{array}{l}\text { (Cultivation and) Usage of shared assets within communities, potentially including shared } \\
\text { ownership }\end{array}$ \\
\hline & & $\begin{array}{l}\text { (Educational) Consumer } \\
\text { engagement }\end{array}$ & $\begin{array}{l}\text { (Open-source) Knowledge sharing to change customer preferences and/or diffuse distinct CE } \\
\text { practices, materials or processes }\end{array}$ \\
\hline \multirow[t]{6}{*}{$\begin{array}{l}\text { Source (focal } \\
\text { organisation) }\end{array}$} & Core technology & Source material & $\begin{array}{l}\text { Substitution of source materials with less resource-intensive, novel alternatives (bio-based, } \\
\text { more durable, biodegradable, recyclable) }\end{array}$ \\
\hline & & Product design & $\begin{array}{l}\text { Increase interchangeability, upgradability, modularity, energy-efficiency or maintainability } \\
\text { of products and product components }\end{array}$ \\
\hline & & Key process & Novel production method or innovation of sub-processes enabling circularity \\
\hline & Enabling technology & Sharing platform & $\begin{array}{l}\text { Enables increased product utilisation rate and reduced material throughput through shared } \\
\text { use/access/ownership }\end{array}$ \\
\hline & & Trading platform & (Web) Platform to facilitate the exchange and resale of products and materials \\
\hline & & Asset tracking & $\begin{array}{l}\text { Tracking of products/components to enable adequate end-of-life treatment or create } \\
\text { transparency on resource availability and origin }\end{array}$ \\
\hline \multirow{3}{*}{$\begin{array}{l}\text { Upstream } \\
\text { (suppliers, } \\
\text { partners) }\end{array}$} & Industrial symbiosis (IS) & Input-oriented & $\begin{array}{l}\text { Structured inter-organisational collaboration to create value from residual resource streams } \\
\text { of external organisations or usage of shared assets }\end{array}$ \\
\hline & & Output-oriented & $\begin{array}{l}\text { Structured inter-organisational collaboration to create value from residual resource streams } \\
\text { of focal organisation or usage of shared assets }\end{array}$ \\
\hline & $\begin{array}{l}\text { Circularity standards/ } \\
\text { accreditation }\end{array}$ & $\begin{array}{l}\text { Sourcing, manufacturing, } \\
\text { transport/packaging }\end{array}$ & $\begin{array}{l}\text { Establishing of process/material standards with suppliers through knowledge sharing and } \\
\text { backward integration of activities along the supply chain }\end{array}$ \\
\hline
\end{tabular}

Source: constructed by authors.

building theory where it is argued that new technologies or innovations require a favourable socio-economic embedding to be successful (Hekkert et al., 2007; Planko et al., 2016). The downstream and upstream activities are, therefore, those directly related to sociological, institutional change because they entail modifications of the relationships with other actors in the value chain (e.g. in terms of changes in ownership, consumption habits or collaborative practises along the supply chain) and thereby can create legitimacy for the focal organisation. Activities primarily determined by the direct goals of the focal organisation - which are subsequently achieved through market acceptance or favourable market structures for their developed goods and services - are mainly technological, i.e. source (Carvalho et al., 1999, 2017). Since only one start-up's business model in the entire sample turned out to be service-based (maintenance etc.) and including ownership transfer to the customer (Amsterdam-based Fairphone), only archetypes where the producer retains ownership were included as PSS in the CBM framework. Following, integration-oriented PSS, product-oriented PSS and service-oriented PSS (as defined by Neely, 2008; Pereira Pesoa et al., 2017; Tukker, 2004; Wallin et al., 2013) are not included based on an inductive approach. (Customer) experience orientation is considered a value element (Tukker, 2004) or antecedent of value (Schallehn et al., 2019) of a PSS business model but not an archetypal model on its own.

The difference between core and enabling technology (Potting et al., 2017) within source activities is that the former is specific to a certain product or process, while the latter can be applied to many industries and across social, technological, economic and cultural systems (Allenby, 2010). Within downstream activities, the authors distinguished between consumers' active involvement and the adoption of PSS models (Ren et al., 2019; Tukker, 2004; Tukker, Tischner, 2006; Vezzoli et al., 2015). The major difference between these two innovation categories is that in PSS, the producers remain owners of the product (Tunn et al., 2019), while in active involvement, they could only facilitate the (shared) consumption and return of externally owned products. For this research, reverse logistics is understood as (technical) materials routed reversely to the main resource flow, which corresponds with a still dominant view in academic literature (Bernon et al., 2017; Carter, Ellram, 1998; Lambert, Stock, 1982; Murphy, 1986; Murphy, Poist, 1988; Rogers, Tibben-Lembke, 1999). Therefore, reverse logistics are an enabler for a multiplicity of value creating CBM innovations (PSS, IS, Return/Repair/Reuse; Farooque et al., 2019; Spring, Araujo, 2017) and run transversally across the categories presented in Table 3, but are not a stand-alone innovation type. The following section describes the methodology followed to collect and analyse empirical data with the help of this theoretical framework to further illuminate the circular business model strategies and innovations developed by CSUs.

\section{Material and methods}

\subsection{Regional and organisational scope}

The three hubs under scrutiny were chosen because they host a vibrant movement towards circularity driven by public and private organisations. Table 3 provides examples of initiatives aiming at strengthening the development of CE and/or circular start-ups in these locations. In addition, they are key hubs for start-up activity, often positioned in the top five European start-up hubs (e.g. European Startup Initiative, 2017). These start-up hotspots are thus likely to host the circular innovations that are essential to consider if one seeks to understand how the future of CE will look like. In addition, many CSUs were expected to be found in these locations. Only firms corresponding to the definition of CSUs presented in Section 2 were included in the analysis.

A list of 128 CSUs was created to present a comprehensive overview of CSUs in the three geographical areas under scrutiny (see appendix for a full list). The search for CSUs was performed until no additional organisation could be found, with the view of having a list that was as exhaustive as possible. A total of 68 (54\%) companies are located in the Randstad region, 28 (22\%) are from Berlin and 31 (24\%) are from London. The companies were identified through the existing resources of their respective municipal authorities, and via CSU awards and circular hubs (see appendix). Data were collected using three main sources: 
Table 3

CE initiatives in scrutinized hubs.

\begin{tabular}{|c|c|c|}
\hline Region/city & Rationale & Source \\
\hline $\begin{array}{l}\text { Randstad (Amsterdam, } \\
\text { Rotterdam, The Hague, } \\
\text { Utrecht) }\end{array}$ & $\begin{array}{l}\text { - Setup of acceleration program in Amsterdam to facilitate knowledge exchange, funding } \\
\text { and networking for anyone pursuing innovative CE concepts } \\
\text { - Rotterdam launched a CE initiative, hosts circular innovation hub (BlueCity010) and one } \\
\text { of the municipalities communicated measures to embed CE in the region is through } \\
\text { attracting CSUs }\end{array}$ & $\begin{array}{l}\text { Veen, n.d.; Amsterdam Smart City (2017); } \\
\text { Gemeente Rotterdam (2016); Hofnaegels } \\
\text { (2016) }\end{array}$ \\
\hline Berlin & $\begin{array}{l}\text { - Berlin is the base for more than } 400 \text { companies identifying themselves as circular and } \\
\text { has more than } 8000 \text { employees in this sector } \\
\text { - Recently, 'CRCLR'a was launched in Berlin, a think- and do-tank dedicated to CE on more } \\
\text { than } 2500 \text { sqm }\end{array}$ & Berlin Business Location Center (2017) \\
\hline London & $\begin{array}{l}\text { - The London Waste and Recycling Board (LWARB) launched the 'Circular London' and } \\
\text { 'Advance London' initiatives in 2018, aiming at strengthening collaborations and } \\
\text { stakeholder engagement around CE, and enabling small- and medium-sized companies to } \\
\text { leverage the benefits of CE }\end{array}$ & London Waste and Recycling Board (2017) \\
\hline
\end{tabular}

${ }^{\text {a }}$ CRCLR is a hub and think- and do tank for CE in Berlin.

- Publicly available information from the websites and social media of start-ups as well as relevant press articles;

- Existing case studies in the grey literature describing these start-ups; and, for part of our sample,

- Semi-structured interviews with founders. These interviews were intended to obtain a more in-depth understanding of the business models of CSUs and the CBM strategies they implement.

Overall, interviews were conducted with 30 of the identified CSUs: 10 in the Netherlands, 14 in Berlin and 6 in London. They were selected to cover the diversity of sectors of activity and of business models that was found in the entire dataset and interviewees were selected via snowball sampling (Kirchherr \& Charles 2018). Interviews, which lasted between 45 and $75 \mathrm{~min}$, were conducted face-to-face or via telephone or Skype. All interviews were audio-recorded and transcribed. Data about companies' background were also collected, including the sector of activity, date of foundation, number of employees, client focus (B2B, B2C or both) and, when available, annual result or revenue. ${ }^{6}$

\subsection{Data analysis}

To answer the research questions, the authors systematically analysed the data collected from all three sources, using a content analysis (Krippendorff, 2013; see Fig. 2). First, all extracts which referred to the business models of CSUs were collected and stored in the coding software. Next, a coding framework (further explained in Section 2.2) was developed to enable the authors to convert qualitative information into numeric data (Bourque and Dudek, 2004). To do so, both deductive categorisation, which uses higher level existing categories from the literature (in particular the categorisations presented in Section 2, such as Urbinati et al.'s (2017) distinction between upstream and downstream companies or Kirchherr et al. (2017) 4R-framework), and inductive categorisation, which uses lower level codes (e.g. specific CBM innovations and strategies developed by CSUs) which are being grouped into higher level codes, were employed to develop the coding categories (Hsieh, Shannon, 2005). Coding categories had to be mutually exclusive and collectively exhaustive.

The information collected about the business model of CSUs was then carefully examined and manually coded according to this coding framework, following an initial set of coding rules. For example, a start-up substituting product components with more

\footnotetext{
${ }^{6}$ The final dataset was established in February/March 2019; founders' interviews
} were conducted between September 2017 and October 2018. sustainable materials was coded as the CBM strategy 'Reduce', while a company using external residual resource streams was coded into the innovation category 'Industrial symbiosis'. To ensure the validity and reliability of the research design, the coding exercise was first completed by two authors separately, who respectively coded half of the sample and then discussed results with each other. In case of diverging coding results, the coding rules were reconsidered, possibly leading to their modification - a good practice to enhance reliability in manual coding (e.g. Hruschka et al., 2004; Neuendorf, 2016).

In practice, the R-strategies often cannot be clearly separated. A product made of multiple components frequently requires the combination of several Rs (Reike et al., 2018), or a business model may simultaneously embrace various CBM strategies. Therefore, the coding procedure allowed for a dominant R-strategy and multiple secondary R-strategies. For instance, a start-up can adopt 'Reduce' as a dominant strategy by developing a less resourceintensive material and, at the same time, encourage the reuse of its products. The decision regarding the dominant R-strategy was made on a qualitative basis (i.e. what is considered the key value driver of the business model) and was complemented with the inputs from the founders of the respective CSUs. Similarly, the coding procedure allowed for a multiplicity of circular innovations to depict the practical (hybrid) realities of the business models analysed. For instance, a start-up could adopt a product design that facilitates reparability (innovation in the core technology), while organising part of its activities as a PSS. There was no dominant innovation type per start-up determined due to lack of insight and missing scientific context. Since some of the innovation types fall in the same innovation categories as per the framework presented in Table 2, the absolute number of innovation types is bigger than the number of innovation categories developed by the CSUs.

As a next step, a frequency analysis was performed to measure the quantitative counts of the different codes. This enabled the authors to assess the relative significance of the CBM strategies and innovations developed by CSUs. In addition, CBM strategies of CSUs could be compared to those adopted by corporate actors, based on the data from a previous study using a similar methodology for 46 corporates (Stewart, Niero, 2018). Since there are no studies categorising corporates' CBM innovations in a similar manner based on the framework used in this research, there was no comparison made between corporates and CSUs in this respect. Finally, the authors also analysed the relationship between CBM strategies and innovations by looking at the type of CBM innovations per respective dominant $\mathrm{CBM}$ strategy. By doing so, the authors could identify the five most relevant combinations of CBM innovations and strategies in the dataset. These five combinations provided the 


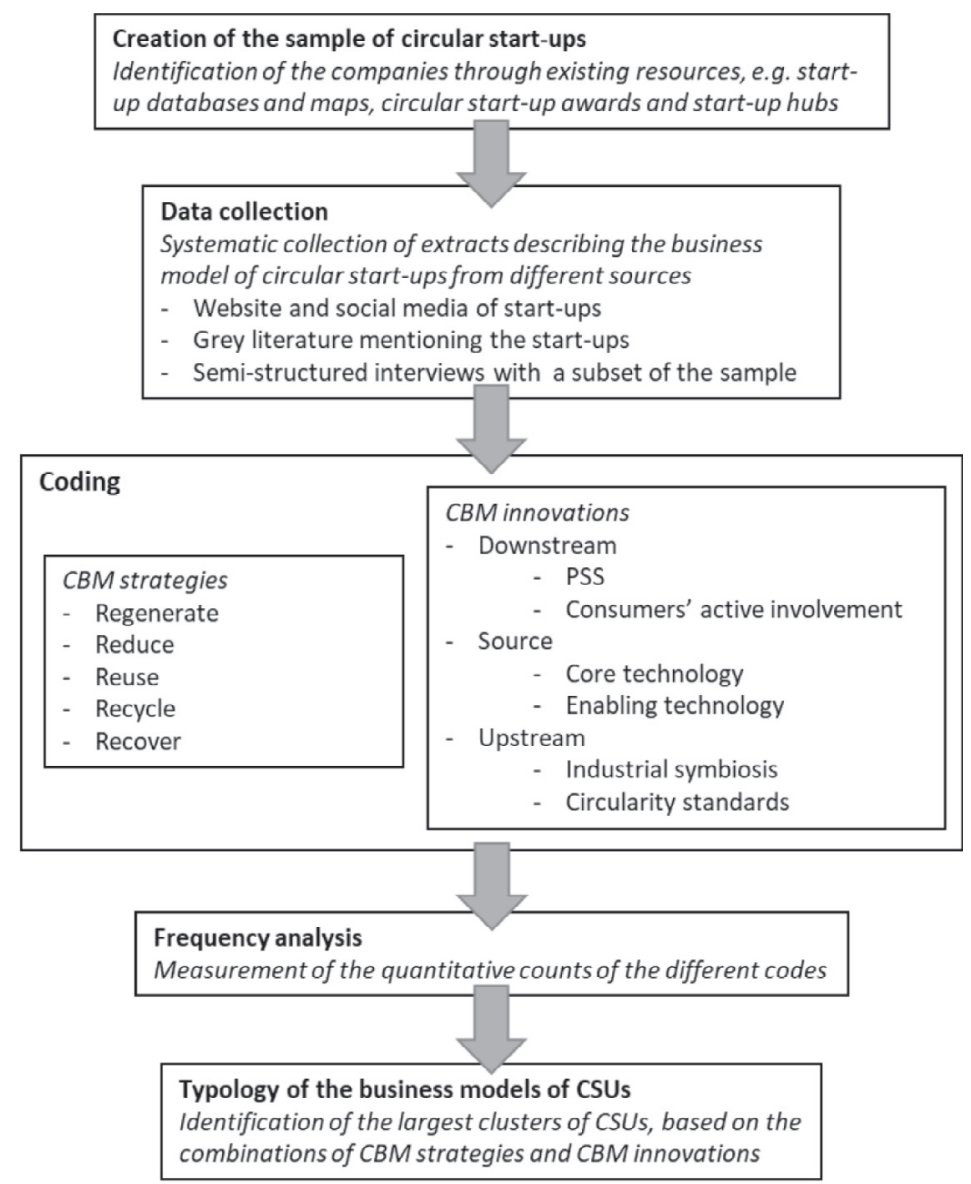

Source: constructed by authors.

Fig. 2. Methodological procedure followed.

Source: constructed by authors.

basis for developing a typology of business models of CSUs, which enabled the authors to unambiguously classify more than $90 \%$ of CSUs in the dataset.

\section{Results and discussion}

\subsection{Sector and market overview}

The most dominant sector within the dataset is agriculture/food (27\%). Other sectors strongly represented in the hubs are manufacturing/materials engineering and built environment/ design (see Fig. 3). The emphasis on food is not surprising from a market perspective, since inefficiency in food-supply chains is pressing and evident, especially in developed countries (Buzby, Hyman, 2012; Ribeiro et al., 2018; Thi et al., 2014), and corporates active in the food sector do not tackle waste management appropriately, mostly due to food-grading systems and lack of actor coordination (European Commission, 2016; Hyde et al., 2001; MartinRios et al., 2018; Stewart, Niero, 2018). In total, 46\% of CSUs examined deploy business models in the biological cycle, while only $7 \%$ of corporates, that are active in only one of the cycles, do (Stewart, Niero, 2018; 75\% of CSUs are in the biological cycle if sectors are matched with reference study which focuses on corporates in FMCG, also see footnote 10). Indeed, multiple value models, in which sequential cash flows can be generated from waste in biological cycles, are predominantly adopted by start-ups. Big companies seem to fail to integrate such novel ways of value creation (Bocken et al., 2017).

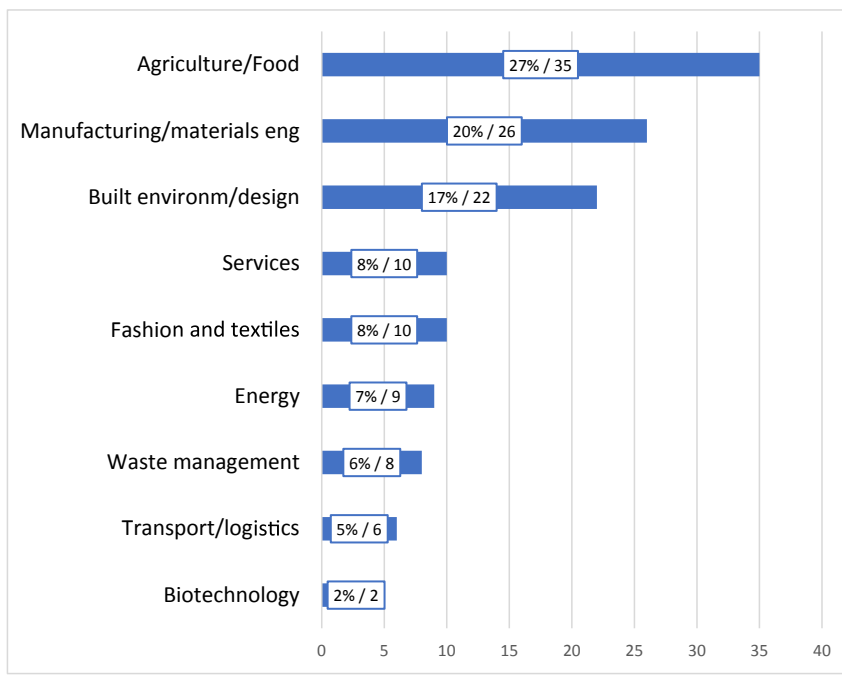

Fig. 3. CSU sector overview. Relative share in \%/absolute share in \# 


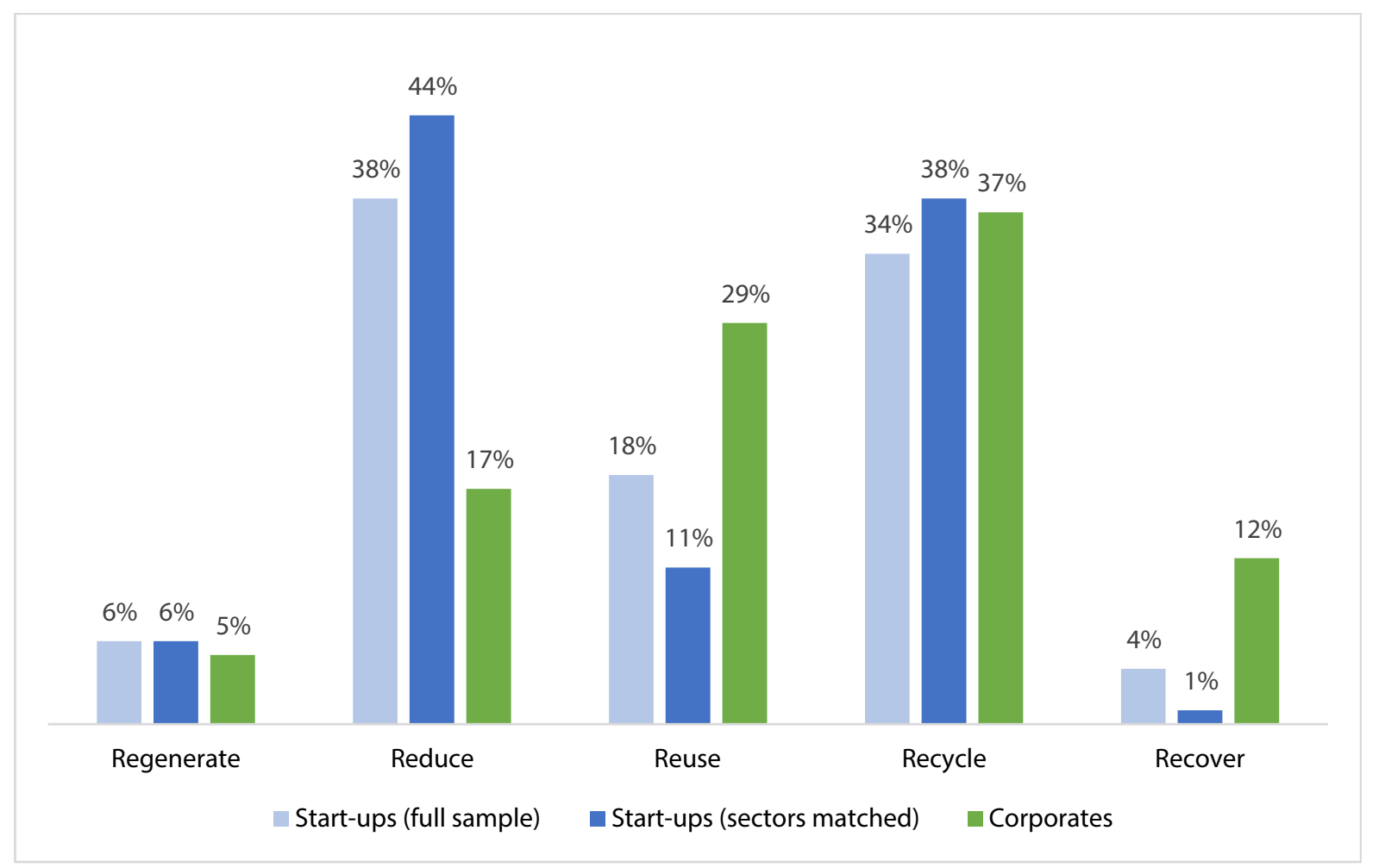

Fig. 4. CBM strategies: CSUs vs incumbents.

Note: Share (in \%) of all R-strategies pursued.

\subsection{CBM strategies and innovations}

The findings on CBM strategies show that CSUs tend to adopt higher ranked CBM strategies than incumbents (Regenerate, Reduce; see Fig. 4). The companies (mostly incumbents) scrutinized in the reference study were only included when listed in the EMF's CE100 directory (Stewart, Niero, 2018) and can therefore be considered frontrunners implementing CE. Previous research suggests that, although CE is increasingly integrated into the corporate sustainability agenda, the focus is drawn on end-of-life management while the adoption of business models incorporating higher levels of circularity is less prevalent (Bocken et al., 2017; Stewart, Niero, 2018). Out of the higher-ranked CBM strategies, incumbents are more strongly represented only in the 'Reuse' concept. This can be explained by two facts: first, reverse logistics, which would allow for a second use cycle of a technical product, are complex and costly (Neely, 2008; Ramanathan, 2011; Ravi et al., 2005); larger companies tend to have better resources to set up

\footnotetext{
${ }^{7}$ An exclusion to this might be catalytic goods like cooling water, i.e. "materials that are necessary to speed up chemical reactions without being used up in the process" (Stahel, 2010, p. 21). They are mostly relevant in the chemical industry, in which none of the CSUs in the data sample operates.

${ }^{8}$ Evaluation based on analysis of multiple (dominant and secondary) R-strategies pursued per organisation (avg. corporates: 2.64; avg. start-ups: 1.46). CSU's circularity strategies were coded (see 3.) The data for corporate circularity strategies was proportionally scaled from the base of all organisations analysed to the base of all strategies identified due to different sample size and organisation sizes; only concretely mentioned circular activities were counted; the original coding in the reference study did not include 'Regenerate'; to adjust for this and following the abovementioned logic, R-related activities in company reports studied that relate to 'Design for Regenerative Systems' are included in the graph as the 'Regenerate' strategy by corporates (5.3\%; deducted from 'Reduce' strategy since this is the only strategy whose coding keywords contained the term "design" in the original study's 4R mapping). Source: Stewart, Niero (2018)..
}

an adequate take-back management (Veleva, Bodkin, 2018). Secondly, the technological cycle is dominant among incumbents innovating in CE (Stewart, Niero, 2018) and 'Reuse' is the CBM strategy that mostly covers tech-related business models; goods in the biological cycle are rather of single-use nature, at least for the same or similar purpose of use. ${ }^{7}$ In terms of incumbents' activity in 'Regenerate', Stewart and Niero (2018) give indications on corporates' approaches taken through including the strategy 'Design for Regenerative Systems' (Moreno et al., 2016) in their analysis (base for calculation in Fig. $4^{8,9}$; see footnote 9 for detailed calculation approach).

The innovations realised by the start-ups are mostly around socio-institutional change (see Fig. 5); more than three quarters of the start-ups innovating in the core technology combine this with socio-institutional innovation. Thus, CSUs act in alignment with the theoretical view that new technology must build up the required socio-institutional embedding and have to be diffused in society to be successful (Geels, 2005; Boons, Luedeke-Freund, 2013; Hekkert et al., 2007), despite the higher complexity of driving factors of socio-institutional change comparing to technological change (Fuenfschilling, Truffer, 2013). CSUs address this primarily by actively involving customers ( $40 \%$ of CSUs) and working with inter-organisational waste streams ( $50 \%$ of CSUs). The high share of customer involvement activities partly contradicts Boons and Luedeke-Freund's (2013) findings on the successful marketing of sustainable innovations, since it can be argued that Collaborative Consumption or Return and Repair includes a shift - or at least the sharing - of the focal organisation's socio-ecological burdens to its

\footnotetext{
9 'Start-ups (sectors matched)' include only CSUs from sectors Food/beverages, Packaging, Fashion, Consumer/Household goods (53 CSUs) to allow for better comparability with Stewart and Niero (2018) data set.
} 


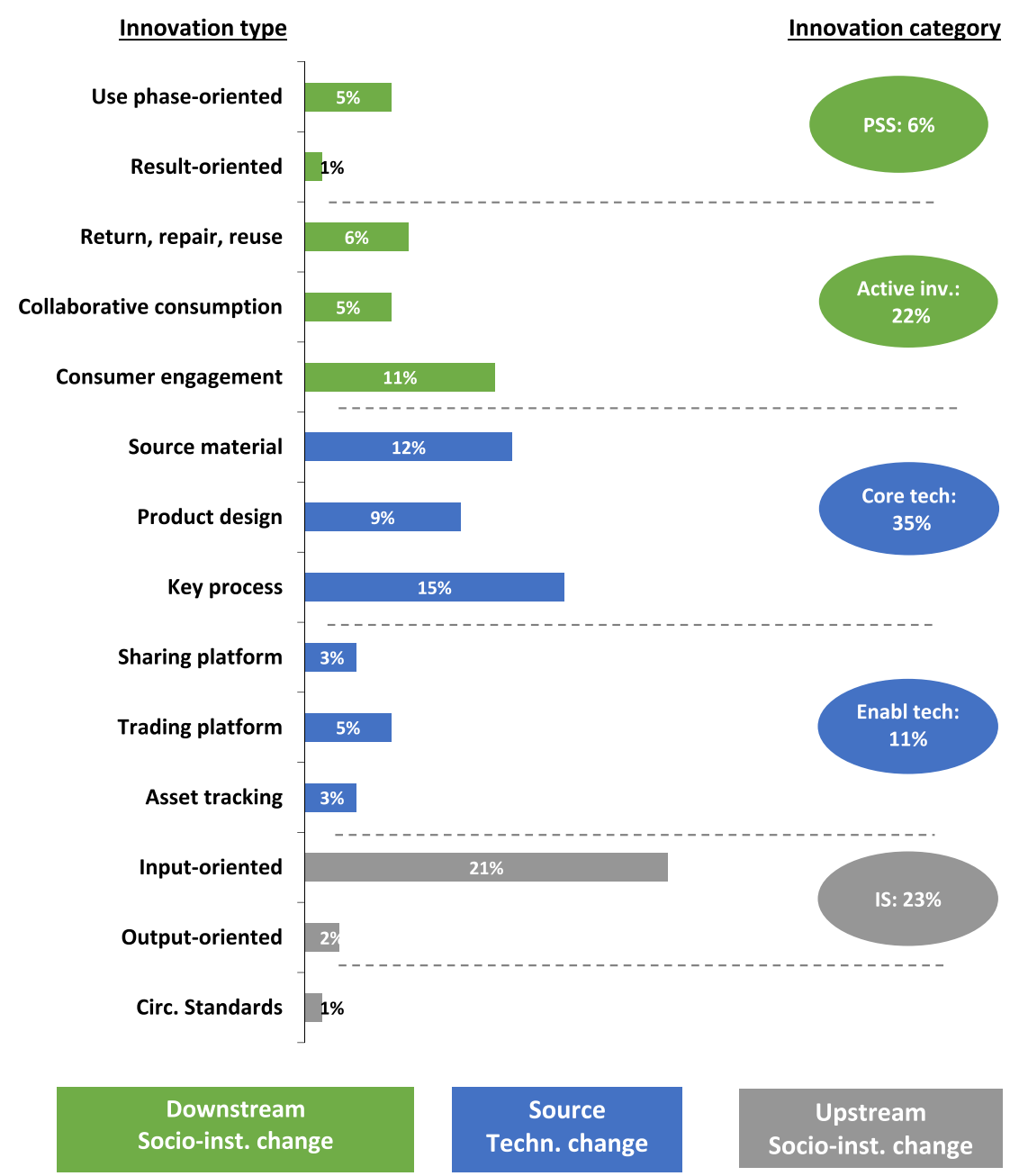

Fig. 5. Circular business model innovation types \% of all innovation types ( 285 in total).

Note: Multiple innovation types per start-up were considered; on average, 2.22 innovations pursued per CSU.

customers. However, it sheds light on the central question posed by Hall et al. (2010) on how start-ups and entrepreneurs will influence a societal transformation towards sustainability. Combined with the close ties of the CSUs with societal actors, (core) technological innovation is driving more than half of the start-ups. Core-technology innovations, the most represented innovation category, range from nickel-iron batteries, to fungus-based construction materials, or bubble barriers to filter plastic from rivers. Lastly, it can be observed that CSUs do not necessarily formally engage with suppliers in circular supply chain management (circularity standards), which is considered pivotal for the marketing of sustainable innovations (Boons, Lüdeke-Freund, 2013; Seuring, Müller, 2008).

\subsection{Towards a typology of circular start-ups}

The typology of CSUs is based on the various innovation categories pursued and on the dominant R-strategies per venture (see Fig. 6) identifying the biggest clusters in the dataset and thereby creating additional structural insight into the approaches taken to develop CBMs. Based on this analysis and derived from the data gathered, a typology of CSUs contrasting five main archetypes was established. The following presentation and discussion of results is structured along these five typologies (Table 4). In case one CSU fell into several innovation categories, the CBM strategy was used as the decisive criterion. This is due to the fact that the authors assigned a dominant CBM strategy to each CSU and only this was taken into account for the development of the typology.

Based on the typology outlined in Table 4, there is a marginal number of seven cases of CSUs that would fit to more than one cluster. For these, the authors applied a qualitative assessment based on the concrete type of innovation pursued and the key elements of the business model. For instance, there are two PSSoperating CSUs also innovating in core technology, substituting one component of their product with reusable source material or designing for reuse. These are still in the cluster of service-based start-ups since the core-technology innovation is a means to an end for them. Only four start-ups did not fit the typology presented in Table 3 (e.g. circular city tours, bio-tech filters for urban air) and are not included in any of the archetype clusters.

\subsubsection{Design-based start-ups}

This cluster of start-ups includes business models dominantly combining the R-strategy 'Reduce' with innovation in core technology and is the biggest group within the sample (37\%). The high share of design-based start-ups can be explained by the high circular ambition of CSU founders, and thus the dominance of the 'Reduce' strategy, as well as the correlation of 'Reduce' and the most dominant innovation types (core-technology). More than twothirds of start-ups (42 of 61) with a dominant 'Reduce' strategy innovate in core technology. This echoes the dominant scientific 


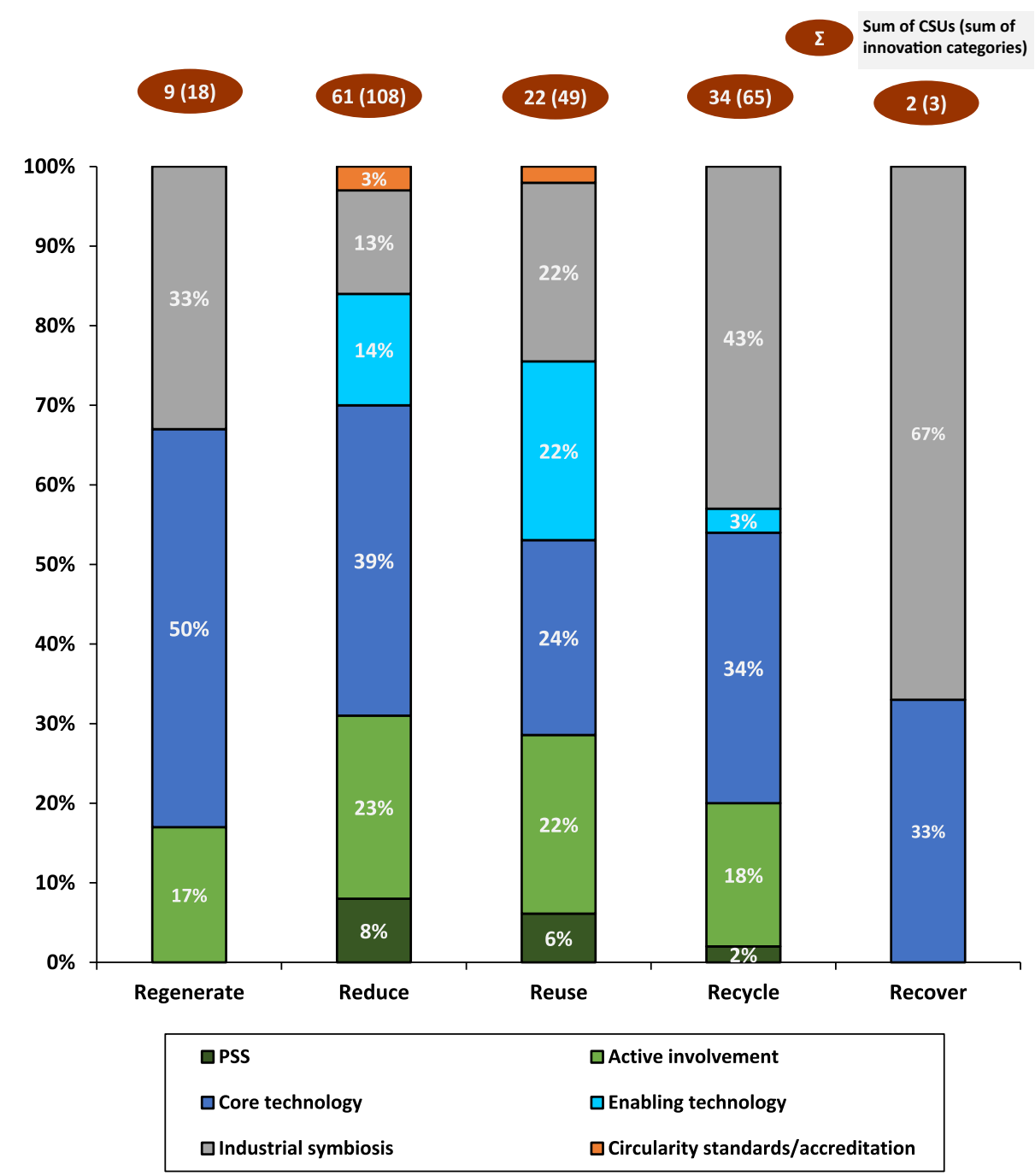

Fig. 6. Innovation categories of circular start-ups per R-cluster. \% of total innovation categories in respective R-strategy cluster ( $\mathrm{n}=243$ ). Note: Analysis based on the dominant R-strategy only and multiple innovation types per start-up.

Table 4

Categorisation criteria and definition for CSU typologies.

\begin{tabular}{|c|c|c|c|c|}
\hline $\begin{array}{l}\text { CSU } \\
\text { archetype }\end{array}$ & CBM strategy & $\begin{array}{l}\text { Innovation } \\
\text { category }\end{array}$ & Definition & $\begin{array}{l}\text { Share of data } \\
\text { sample }(n=128)\end{array}$ \\
\hline $\begin{array}{l}\text { Design- } \\
\text { based }\end{array}$ & $\begin{array}{l}\text { Reduce/ } \\
\text { Reuse }\end{array}$ & $\begin{array}{l}\text { Core } \\
\text { technology }\end{array}$ & $\begin{array}{l}\text { Aiming to increase usage efficiency or avoid residual resource streams, design-based CSUs adopt circular } \\
\text { innovations mostly in the pre-market phase of their product or service through source material } \\
\text { minimization, product design or production process efficiency. }\end{array}$ & $36 \%$ \\
\hline $\begin{array}{l}\text { Waste- } \\
\text { based }\end{array}$ & $\begin{array}{l}\text { Recycle, } \\
\text { Recover }\end{array}$ & $\begin{array}{l}\text { Industrial } \\
\text { symbiosis }\end{array}$ & $\begin{array}{l}\text { Waste-based CSUs seek to extract value from unexploited external waste streams (e.g. recycled plastic, } \mathrm{CO}_{2} \text {, } \\
\text { surplus food) mostly based on innovative process solutions. }\end{array}$ & $27 \%$ \\
\hline $\begin{array}{l}\text { Platform- } \\
\text { based }\end{array}$ & Various & $\begin{array}{l}\text { Enabling } \\
\text { technology }\end{array}$ & $\begin{array}{l}\text { Platform-based CSUs pursue business models built around B2B, B2C or C2C marketplaces for (excess) } \\
\text { resources. Thus, they facilitate trading or sharing of products, knowledge, infrastructure or services. }\end{array}$ & $19 \%$ \\
\hline $\begin{array}{r}\text { Service- } \\
\text { based }\end{array}$ & Various & PSS & $\begin{array}{l}\text { Service-based CSUs embed products in a service-system without customer ownership of the physical good } \\
\text { aiming for higher, and better controllable usage efficiency. }\end{array}$ & $9 \%$ \\
\hline $\begin{array}{l}\text { Nature- } \\
\text { based }\end{array}$ & Regenerate & Various & $\begin{array}{l}\text { Nature-based CSUs' operate nature-based systemic solutions to deliver services (or products) with the } \\
\text { objective to lower input of non-renewable natural capital and increase investment in renewable natural } \\
\text { processes. }\end{array}$ & $6 \%$ \\
\hline Other & $\begin{array}{l}\text { Reduce, } \\
\text { Reuse, } \\
\text { Recycle }\end{array}$ & Various & $\begin{array}{l}\text { CSUs operating natural urban air filters, circular city tours or apply several CBM strategies and innovation } \\
\text { types. }\end{array}$ & $3 \%$ \\
\hline
\end{tabular}

Note: mutually exclusive archetypes, dominant criterion for archetype stated in Georgia/Italics.

view connecting 'Reduce' predominantly with innovation in source material and product design and, therefore, mostly with activities during the pre-market phases of the product lifecycles (Jayal et al.,
2010; Lieder, Rashid, 2016; Reike et al., 2018; Sihvonen, Ritola, 2015; Worrell, Reuter, 2014). This CSU cluster includes companies striving for source material minimization (e.g. fungus as 
construction material), process efficiency (e.g. low-cost infrastructure biomass growing), or innovators in product design (e.g. electricity-independent medical refrigerators).

Despite the common focus on the pre-market phase, the findings also suggest that design-based start-ups could be relevant micro-level innovators regarding integrating upstream-related and, especially, downstream-related - activities in CBMs. More than half of the start-ups in this cluster complement their core technology innovations with innovations in active customer involvement or IS. Amsterdam-based Kartent is one example of such a start-up. Kartent designed a festival tent made entirely from cardboard. This product design innovation is embedded in a business model that requires customers to change consumption patterns (ordering the tent for a festival, returning after usage) and utilises existing supply chains to create value from the waste streams (used tents processed into boxes for logistics industry or festival gadgets). Literature suggests that it is a key challenge for corporates to include customers in their circular endeavours and create awareness among them (Kirchherr et al., 2017; Young et al., 2018). This however, is considered critical for the development of CBMs and an eventual transition to a CE (Hazen et al., 2017; Linder, Williander, 2017; Veleva, Bodkin, 2018), whereby CSUs could be necessary pioneers in successfully applying such business models.

\subsubsection{Waste-based start-ups}

Waste-based start-ups are the second largest group (27\%) of organisations in the dataset. They pursue the lower-ranked Rstrategies 'Recycle' and 'Recover' as their dominant circular strategies and commonly innovate in IS (>95\% of all Recycle and Recover start-ups). IS is a commonly known concept (Chertow, 2000) and is increasingly considered a tool for the implementation of CE (Baldassarre et al., 2019; Bocken et al., 2014; Domenech et al., 2019; Forum for the Future, 2016; Mortensen, Kørnøv, 2019; Prosman et al., 2017). Recycled materials mostly stem from post-consumer products or post-producer waste streams and are called secondary materials since they often lose their fit to the original use case and can be re-applied anywhere (Worrell, Reuter, 2014; Graedel et al., 2011; Jawahir et al., 2006; King et al., 2006). Three of the start-ups in this cluster pursue a 'Reuse' strategy, upcycling residual resource streams in the fashion sector. Since these companies do not innovate in the product design (e.g. yoga bags, backpacks) or develop a new material, wherefore they are allocated to the waste-based cluster. Start-ups in this category include organisations turning recycled plastic into marble tiles or community-based organisations, such as recyclers of surplus food.

Only one-fifth of the start-ups using the 'Recycle' and 'Recover' strategies that innovate via IS are primarily in the wastemanagement sector. The sectoral focus of the start-ups is on agriculture/food (35\%), whereby recycling/recovering seems to be rather a means to an end than an end in itself. More than two-thirds of companies in this cluster combine IS with core-technology innovations in source material or key processes. While key process innovations in 'Recycling' can involve growing mushrooms from coffee waste, there are also more breakthrough process innovations included, such as turning $\mathrm{CO}_{2}$ and sunlight into organic compounds. An example for a source-material innovation is Rotterdambased Refil, which develops fully recycled 3D-printing filaments made from car dashboards and old PET bottles. The CSUs active in 3-D printing produce a waste stream-based filament or offer it through local recycling systems (e.g. of waste plastic). These types of offerings correspond with Despeisse et al. (2017) findings and represent two of the three focus categories of activities combining 3-D printing and CE (the third use case being 3-D printing for repair or remanufacturing).

The development of supply chain networks is often initiated by the acting players themselves due to lack of legislative clarity about by-products and waste streams. Across Europe, ${ }^{10}$ there are a significant number of self-organising industry networks striving for circularity through IS (Domenech et al., 2019). In the expert interviews, founders in this cluster stated that they tend to face regulatory problems, as in some markets, like Germany, resources that have been declared as waste cannot be reused but must be disposed of, or require licenses allowing for further processing ('Waste-material sourcing requires specific licenses, and the tax on it is too high, in my opinion', Interviewee A). Therefore, the companies using waste as resources tend to establish informal networks to disrupt the established supply chain, as, for instance, half of the Berlin participants of the expert interviews stated when asked for major external challenges ("...] [the source material] is officially a waste product, so there are regulatory barriers regarding working with this material. Here, we rely on our entrepreneurial spirit and just go ahead without having regulatory clarity', Interviewee $\mathrm{B}$; '[We are facing a] lack of regulation in terms of declaration of waste material and how to handle it', Interviewee C).

\subsubsection{Platform-based start-ups}

This archetype of start-up has, at its core, business models built around marketplaces for excess or idle resources mainly from the construction, fashion or home-appliances sector. The dominant CBM strategies represented here are 'Reduce' and 'Reuse'. The fact that platform-based business models are the third-largest category (20\%) in the overall sample of CSUs can be explained by the general low-labour intensity and thus low entry barriers, as well as the diffusion of peer-to-peer platforms as key enablers of the growing sharing and circular economy (Ellen MacArthur Foundation, 2015; Ritter, Schanz, 2019). Sharing platforms are the dominant innovation type among start-ups pursuing a 'Reduce' strategy within this cluster ( 7 out of 11 Reduce start-ups). Taking a closer look at the forms of value creation on the platforms, van Dijck et al. (2018), Potting et al. (2017) and Konietzko et al. (2019) seem to be confirmed in their views that (online) platform business models are rather facilitators of economic transactions (trading, sharing) than bases for co-creation - i.e. sharing knowledge or debating/learning together. Only three of the 26 start-ups in this cluster focus on cocreation (e.g. Materiom, an open-source material database), while more than $90 \%$ of platform-based business models only enable sharing or trading.

In the context of platforms and their roles in a CE, Konietzko et al. (2019) ${ }^{11}$ mention the value of usage data - e.g. to inform maintenance or repair needs of products. Additionally, the Ellen Macarthur Foundation et al. (2019) discuss the example of a trading platform for secondary resources with a focus on pricing algorithms and forecasting. A total of four of the 26 platform-based start-ups have a distinct focus on this kind of value creation via asset tracking. While one of the CSUs in this cluster develops a platform solution helping organisations and their networks transitioning towards circularity through business and artificial intelligence $(\mathrm{AI}),{ }^{12}$ the others use technology to track resources and product components. Berlin-based Design for Circularity developed a radio-frequency identification (RFID) label on clothes that grants consumers and sorting companies access to a member-based platform containing information on the inherent materials as

\footnotetext{
10 Italy, Germany, Scandinavia.

11 Apart from trading/sharing and co-creation, Konietzko et al. (2019) define a third role platforms can play in the CE transition, which is to operate PSSs. PSSbased business models are a distinct typology in this analysis. These types of start-ups are clustered and explained in section 4.3.4.

12 UK-based Winnow uses AI to monitor food waste in food service companies.
} 
well as on the recycler the product should go to at end of life. Another CSU example of advanced technology used for asset tracking is Excess Materials Exchange, which uses blockchain technology to facilitate the exchange of excess material among companies. All four CSUs make the data accessible via a multi-user platform, and three of them define their offerings as platforms themselves. Due to this practical evidence, and also since literature connects asset tracking with platforms in CE (Konietzko et al., 2019), this type of innovation is clustered as platform-based.

\subsubsection{Service-based start-ups}

Service-based CSUs operate PSSs in order to better control and increase usage efficiency of their continuously owned products. Interestingly, only one PSS-oriented company in the entire dataset runs a CBM where ownership is transferred to the customer (Fairphone). This indicates that CSUs tend to focus on need-fulfilment systems rather than selling the maximum possible number of products (Stahel, 2010; Tukker, 2015). PSSs financially incentivise the companies to invest in the durability and reuse of products and materials (Baines et al., 2007; Mont and Tukker, 2006; Williams, 2007). Following this focus on more intensive product use, the main CBM strategy pursued by this type of start-ups is 'Reduce'. The driving innovation of developing a PSS is mostly combined with active involvement of consumers through returning or repairing products (10 out of 12 CSUs, e.g. a returnable packaging service for drinks) or collaborative consumption ( 4 out of 12 CSUs, e.g. shared construction spaces and machinery). Involving consumers in reverse supply-chain activities (return, repair, reuse) is considered a promising avenue towards a wider diffusion of CE through PSS business models since it can address the barrier of increased capital requirements of a reverse logistics network (Wastling et al., 2018). Product recovery activities are currently underdeveloped in the CE/ PSS domain, and early customer involvement is considered critical in PSS solution design (Kühl et al., 2018; Luiten et al., 2001; Manzini et al., 2001). Four of the start-ups in this category design products for PSS since they also innovate in product design (e.g. modular phones, modular and biodegradable diapers, reusable batteries).

Despite many scholars considering PSSs as one key driver of circularity in business models and they belong to the most cited practical application methods of the latter (Antikainen and Valkokari, 2016; Bocken et al., 2017; Kühl et al., 2018; Lieder, Rashid, 2016; Stahel, 2010; Tukker, 2015; Yang, Evans, 2019) only $9 \%$ of start-ups pursue this innovation category of moving from customer ownership to performance- and service-based revenue models. The most significant reason for this is that the application of typically asset-heavy PSS business models is often more problematic for small- and medium-sized businesses (SMEs) than large corporates due to lack of (financial) resources and lack of formalised planning (Augusto de Jesus Pacheco et al., 2019; Besch, 2004; Neely, 2008). In general, especially performance-based PSS are considered very difficult to implement due to the difficulty of establishing indicators and requirement of continuous feedback loops with customers (Pereira Pesoa, Jauregui Becker, 2017). Furthermore, the biological cycle is dominant among the CSUs, and PSSs are strongly associated with manufacturing companies in the technical cycle (Augusto de Jesus Pacheco et al., 2019; Copani, Behnam, 2018; Neely, 2008; Yang, Evans, 2019) - 11 out of 12 service-based start-ups operate in the technical cycle, which supports the literature perspective.

\subsubsection{Nature-based start-ups}

The distinctive features of companies in this archetype is that they pursue the highest-ranked category 'Regenerate' and thus not only try to avoid any environmental harm, but also seek to maintain and increase the delivery of (products and) services based on natural ecosystems and nature-based solutions (Maes, Jacobs, 2017). Six percent of all start-ups fall into this category of imitating biological cycles or systems. The only sectors represented are agriculture/food and built environment/design. Examples of such start-ups include Berlin-based 'aquaponic' start-ups, synergising fish farming and plant growing in a symbiotic, selfsupporting environment without the usage of soil ${ }^{13}$ (Campanhola, Pandey, 2019; Kyaw, Ng, 2017). Further representatives of this category are start-ups working on building-integrated plant cultivation and green roofs or London-based Entocycle, which produces protein by feeding food waste to protein-rich, vertically farmed insects to nurture animals or fertilise industrial crop production.

Maes, Jacobs (2017, p. 123) argue that the usage of nature-based ecosystem services always leads to 'decreased input of nonrenewable natural capital and increased investment in renewable natural processes'. This combination of decreased resource usage and adaptation of natural processes corresponds with the results of the data gathering, since all nature-based start-ups combine the dominant 'Regenerate' strategy with 'Reduce', and innovation in core processes is the dominant innovation type. All start-ups focusing on building-integrated solutions work with residual streams from the buildings they plan to redesign, which explains the high share of IS. It is noteworthy that $80 \%$ of the start-ups in this cluster focus on urban systems, which are considered to have the potential to generate major socio-economic benefits addressing the challenges of increasing urbanisation. This is a key application area of nature-based solutions in Europe (European Commission, 2018; Frantzeskaki, 2019; Lafortezza, Sanesi, 2019; Maes, Jacobs, 2017; Vujcic et al., 2017). The low uptake of nature-based solutions thus far is due to missing definition and impact assessment of the concept itself (Canitez, 2019; Kabisch et al., 2016; Krauze, Wagner, 2019), and to lack of awareness among and support from city authorities and their respective urban-development plans (Faivre et al., 2017; Lohr et al., 2004; Kirkpatrick et al., 2013; Kronenberg, 2015).

\section{Conclusion}

This research aimed to conceptualise and create a typology for circular start-ups (CSUs) to explore innovative organisations working on circular economy (CE). Based on the data gathered and the frameworks applied, a typology for CSU business models could be introduced that encompasses more than $90 \%$ of all 128 CSUs scrutinized in the data sample. The major clusters in this typology are

- design-based CSUs, adopting circular innovations mostly in the pre-market phase through source material minimization, product design or production process efficiency,

- waste-based CSUs, seeking to extract value from unexploited external waste streams,

- platform-based CSUs, pursuing sharing/trading business models built around B2B, B2C or C2C marketplaces,

- service-based CSUs, embedding products in service-systems to increase usage efficiency and

- nature-based CSUs, increasing the delivery of (products and) services based on nature-based systemic solutions.

The developed typology contributes to the literature on

\footnotetext{
13 'Aquaponics is one of the food production systems that combined recirculating aquaculture system and hydroponic system by the utilisation of waste material excreted from fish as a liquid fertilizer for valued hydroponic vegetables and seaweeds' (Anpo et al., 2019).
} 
entrepreneurship, sustainability and on sustainable (business model) innovation by better positioning circular start-ups against related concepts, such as sustainable and environmental start-ups, and by examining the actual business models deployed by circular entrepreneurs. Thus, it strengthens the link between the above bodies of research. The analysis shows that the theoretically dominant R-frameworks in the context of circular business models (CBMs) need to be expanded by the additional category 'Regenerate'. The introduction of the concept of nature-based solutions in the conceptual realm of CE strategies is one of the key theoretical contribution of this paper. Additionally, despite being the most common conceptualisation, the R-frameworks are still a relatively abstract and rigid concept when it comes to the transformation of business models for $\mathrm{CE}$. The common scientific perspective that the combination of multiple strategies, methods and approaches is necessary for a shift towards a CE (Bocken et al., 2016, Whalen, 2017 ) is further driven, elucidated and nuanced in this research. The authors developed a CBM framework that goes beyond existing concepts in terms of the 'how-to' of CE through the simultaneous mapping of CBM strategies and innovation types, thus allowing for - and introducing - CBM archetypes pursuing more than one CBM strategy and innovation type. This research adds to existing frameworks in the field of CBM innovation and enables a more detailed perspective on the key actors for circular innovation along the value chain by adding the 'Source' category to existing CBM innovation frameworks (Urbinati et al., 2017).

The novel empirical contributions of this article include the observation that CE strategies pursued by start-ups seem to be of higher hierarchical levels than the ones pursued by corporates. Cumulatively, CSUs compare higher in the strategies 'Regenerate' ( $6 \%{ }^{14}$ vs $5 \%$ ) and 'Reduce' ( $44 \%{ }^{15}$ vs $17 \%$ ). Additionally, CSUs operate more dominantly in the biological cycle than CE-oriented corporates $\left(75 \%{ }^{15}\right.$ vs $\left.7 \%\right)$. PSS business models, even though highly valued by many scholars as CE enablers, are only represented to a small extent among CSUs. This is caused by financial constraints faced by CSUs applying this asset-heavy innovation category, as well as the mismatch of the rather technically related PSSs and the primarily bio-based CSU business models.

This conceptualisation of CSUs will help to understand possible pathways and necessary conditions for the further spreading of the concept of CE, and thus of sustainable development in practice (and theory). Corporates and start-ups striving to become more circular can derive structured transition paths towards CBMs (e.g. guidance on dominant innovation category applied when pursuing a 'Reduce' strategy; full overview in Fig. 6). The results shown can serve as inspiration for circular entrepreneurs in their incubation phase when looking for promising, low-invest business model adaptations for circularity. For instance, the lack of coordinated action for the management of residual resource streams is an indicator for circular founders to invest in their network and social capital early on to create a competitive advantage (see Paunescu and Raluca Badea, 2014; Peng et al., 2018). Policy-makers benefit from a further definition and differentiation of practical concepts in circularity/sustainability. For instance, the current high-level perspective on the implementation of nature-based solutions taken, e.g., by the EU (European Commission, 2015) - could be substantiated with a better understanding of the underlying practical application methods. Additionally, the empirical and conceptual character of this research allow for a better channelling of efforts on policy intervention since the presented typology of CSUs

\footnotetext{
14 Only those CSUs of the dataset are considered that operate in the same sectors as in Stewart and Niero (2018) reference study, i.e. Food/beverages, Packaging, Fashion and Consumer/Household goods (56 CSUs).
}

enables a targeted addressing of relevant stakeholders and their respective needs (with main CE barriers in the EU detailed in Kirchherr et al. 2018).

This research is one of the first of its kind in elucidating business models developed by circular entrepreneurs, however the lack of understanding of the actual sustainability performance of these very business models is a limitation related to it. Thus, hypotheses made on the hierarchy and effectivity of circularity strategies and business models are not substantially backed with representative and comparable metrics. Furthermore, since approximately two thirds of CSUs were not analysed based on direct interviews but outside-in, there is a risk of not every circularity-related activity being captured in the data gathering. This would require a deeper analysis of each start-ups or a direct contact with all the respective organisations. However, the authors consider that the publicly available information about the scrutinized companies contains all the major activities on CE since this is a distinct business focus of almost all of them.

Further research on this topic could consider a comparative analysis of the different geographical areas covered in this study. There were indications (e.g. dominant sectors, CBM strategies pursued) that the different municipal/governmental policies and business ecosystems in the areas analysed led to distinct characteristics of the CSUs active there. A deeper qualitative analysis of the underlying causes and respective market/legislative setups is necessary to gain structured insight into these regional differences. This allows for a more effective intervention management. The prevalent outside-in analysis and selected expert interviews used for this research would therefore need to be enriched, e.g., by interviews with policy-makers or CE experts. Additionally, an extension of the data sample (i.e., including business models and innovation types of CE-oriented corporates) would help to better understand the start-ups' roles in transitions towards CE. Furthermore, it is not clearly defined and structurally assessed regarding which barriers and success factors impact the diffusion of CSU business models. Further research on this could inform policymakers or investors on where to focus their efforts to further drive $\mathrm{CE}$.

The authors are excited about the opportunity to analyse CSUs and their respective CBMS and hope to trigger further scientific work on this relevant topic with this research.

\section{Declaration of competing interest}

None

\section{Acknowledgements}

This research was funded by Friedrich Naumann Foundation and the Dutch Research Council (project number: 438.17.904).

\section{Appendix}

Appendix 1. Overview of founder interviews

\begin{tabular}{|c|c|c|c|}
\hline Number & Location & Start-up & Position \\
\hline 1 & Amsterdam & CocoPallet & Co-Founder and CEO \\
\hline 2 & & DeKlik & Founder and CEO \\
\hline 3 & & Mayya Saliba Design & Founder and CEO \\
\hline 4 & & PickThisUp & Founder and CEO \\
\hline 5 & Rotterdam & Aloha Bar & Founder and CEO \\
\hline
\end{tabular}




\begin{tabular}{|c|c|c|c|}
\hline Number & Location & Start-up & Position \\
\hline 6 & & FruitFlyNinja & Co-Founder and $\mathrm{COO}$ \\
\hline 7 & & Kees & Founder and CEO \\
\hline 8 & & MastersThatMatter & Co-Founder and Creative Director \\
\hline 9 & & Rotterzwam & Co-Founder and CEO \\
\hline 10 & & Vet and Lazy & Co-Founder and CEO \\
\hline 11 & Berlin & aluc & Co-Founder and CEO \\
\hline 12 & & bonaverde & $\mathrm{COO}$ \\
\hline 13 & & Design for Circularity & Founder and CEO \\
\hline 14 & & Diaper Cycle/Dycle & Co-Founder and CEO \\
\hline 15 & & Dzaino & Co-Founder and CEO \\
\hline 16 & & ECOBrotbox & Founder and CEO \\
\hline 17 & & GreenMe Berlin & Founder and CEO \\
\hline 18 & & KAFFEEFORM & Founder and CEO \\
\hline 19 & & Material Mafia & $\mathrm{COO}$ \\
\hline 20 & & mimycri & Co-Founder and CEO \\
\hline 21 & & Mitte GmbH & Business Development \\
\hline 22 & & mundraub & Founder and CEO \\
\hline 23 & & selo & Business Development \\
\hline 24 & & Upcycling Deluxe & Co-Founder and CMO \\
\hline 25 & London & Aceleron & Co-Founder and CEO \\
\hline 26 & & BuildingBloqs & Co-Founder and CEO \\
\hline 27 & & GrowUp & Co-Founder and CEO \\
\hline 28 & & Nimber & Founder and CEO \\
\hline 29 & & Remakery & $\mathrm{COO}$ \\
\hline 30 & & Biohm & Founder and CEO \\
\hline
\end{tabular}

Appendix 2. Circular start-ups in research database $(n=128)$ (continued)

\begin{tabular}{llll}
\hline Circular start-up 1-30 & \multicolumn{2}{l}{ Location Circular start-up 31-60 } & Location \\
\hline MealSaver & GER & SNACT & GER \\
MetroPolder & NL & SolaGrow & GER \\
Mifactori & GER & soulbottles & NL \\
mimycri & GER & Spireaux & UK \\
Mitte GmbH & GER & Squall & NL \\
Moss & NL & STADTFARM & UK \\
Motoshare & NL & StoneCycling & NL \\
mundraub & GER & Straw by Straw & NL \\
New Marble & NL & Sustainer homes & UK \\
Nimber & UK & Sustonable & GER \\
Noesthout & NL & Swapfiets & NL \\
Okkehout & NL & The Cheeky Panda & GER \\
OLIO & UK & The Fungi Factory & NL \\
PENTATONIC & GER & The Great Bubble Barrier & GER \\
Perpetual Plastic & NL & The Waste Transformers & NL \\
Photanol & NL & TOAST & NL \\
PickThisUp & NL & TRYATEC & NL \\
Pinatex & UK & United Wardrobe & GER \\
$\begin{array}{l}\text { Planq } \\
\text { Precious Plastic Den Haag NL }\end{array}$ & Upcycle Society & UK \\
RanMarine Technology & NL & Vpcycling Deluxe & GER \\
Reblend & NL & VanPlestik & NL \\
Refil & NL & Vet and Lazy & NL \\
Refill & UK & Vibers & NL \\
Remakery & UK & Waste2Wear & NL \\
Repurpose & UK & Waste4me & NL \\
Roof Water Farm & NL & Winnow & NL \\
\hline
\end{tabular}

Appendix 3. Overview of the sources used for creating the dataset

\begin{tabular}{|c|c|c|c|}
\hline Circular start-up 1-30 & Location & Circular start-up 31-60 & Location \\
\hline Aeropowder & UK & ENSO & UK \\
\hline Aceleron & UK & Entocycle & UK \\
\hline Aloha Bar & NL & Enviromate & UK \\
\hline Bambooder & NL & E-Stone Batteries & $\mathrm{NL}$ \\
\hline Beeblue & $\mathrm{NL}$ & Excess Materials Exchange & NL \\
\hline Better Future Factory & $\mathrm{NL}$ & Fairphone & $\mathrm{NL}$ \\
\hline bio-bean & UK & Finch Buildings & NL \\
\hline biohm & UK & FruitFlyNinja & NL \\
\hline bonaverde & GER & Fruitleather Rotterdam & $\mathrm{NL}$ \\
\hline BroodNodig & NL & Globechain & UK \\
\hline BrouwBrood & NL & green city solutions & GER \\
\hline BuildingBloqs & UK & Green Lab Berlin & GER \\
\hline Bundles & $\mathrm{NL}$ & GreenMe Berlin & GER \\
\hline Cartoni Design & NL & GRO (Green Recycled Organics) & NL \\
\hline Circular IQ & NL & GrowUp & UK \\
\hline Closing the Loop & NL & HaagseZwam & $\mathrm{NL}$ \\
\hline CocoPallet & NL & Halo Coffee & UK \\
\hline Coffee Based & NL & Harvestmap & NL \\
\hline Community Plastics & NL & HillBlock & NL \\
\hline Concr3de & $\mathrm{NL}$ & Hubble & UK \\
\hline Coolar & GER & hubus-Berlin & GER \\
\hline CupClub & UK & HuisVeendam & NL \\
\hline DACHFARM Berlin & GER & Infarm & GER \\
\hline Design for Circularity & GER & Instock & $\mathrm{NL}$ \\
\hline Diaper Cycle/Dycle & GER & KAFFEEFORM & GER \\
\hline DryGro & UK & Kartent & $\mathrm{NL}$ \\
\hline Dzaino & GER & Kees & NL \\
\hline ECF FARM BERLIN & GER & Kromkommer & $\mathrm{NL}$ \\
\hline ECOBrotbox & GER & LEIHBAR & GER \\
\hline Enerpy & $\mathrm{NL}$ & Library of Things & UK \\
\hline Circular start-up 61-94 & Location & Circular start-up 95-128 & Location \\
\hline Limejump & UK & Rotterzwam & NL \\
\hline Loop.alife & $\mathrm{NL}$ & Rype Office & NL \\
\hline MasterFilter & UK & Scrap Connection & $\mathrm{NL}$ \\
\hline MastersThatMatter & NL & Seepje & NL \\
\hline Material Mafia & GER & selo & NL \\
\hline Materiom & UK & SIRPLUS & UK \\
\hline Mayya Saliba Design & $\mathrm{NL}$ & Skipping Rocks Lab & GER \\
\hline
\end{tabular}

\begin{tabular}{|c|c|}
\hline \multicolumn{2}{|l|}{ Databases and maps } \\
\hline $\begin{array}{l}\text { Amsterdam Economic } \\
\text { Board's CSUs map }\end{array}$ & $\begin{array}{l}\text { http://economicboard.magazines.center/circulaire- } \\
\text { activiteit\#!/startups-in-nederland }\end{array}$ \\
\hline $\begin{array}{l}\text { Startups solutions for the } \\
\text { energy transition }\end{array}$ & $\begin{array}{l}\text { https://www.startupdelta.org/wp-content/ } \\
\text { uploads/2018/09/Startup-solutions-for-the- } \\
\text { energy-transition-\%E2\%80\%94-Bid-book- } \\
\text { StartupDelta.pdf }\end{array}$ \\
\hline StartupDelta database & https://www.startupdelta.org/ \\
\hline $\begin{array}{l}\text { Circular Economy Club } \\
\text { Mapping Week }\end{array}$ & Link \\
\hline \multicolumn{2}{|l|}{ CSU awards } \\
\hline Green Alley Award & https://green-alley-award.com/ \\
\hline CE Booster & https://cebooster.nl/ \\
\hline \multicolumn{2}{|l|}{ CSU hubs } \\
\hline CRCLR, Berlin & https://crclr.org/ \\
\hline BlueCity010, Rotterdam & https://www.bluecity.nl/ \\
\hline $\begin{array}{l}\text { Sustainable workspaces, } \\
\text { Londn }\end{array}$ & https://www.sustainableworkspaces.co.uk/ \\
\hline
\end{tabular}

\section{References}

McKinsey \& Co, 2015. Europe's Circular-Economy Opportunity. McKinsey \& Company, USA.

Accenture, 2014. Circular advantage: innovative business models and technologies to create value in a world without limits to growth. http://tinyurl.com/p4s5a2f.

Adams, R., Jeanrenaud, S., Bessant, J., Denyer, D., Overy, P., 2016. Sustainabilityoriented innovation: a systematic review. Int. J. Manag. Rev. 18, 180-205. https://doi.org/10.1111/ijmr.12068. Available online at:

Amsterdam Smart City, 2017. Circular city [WWW document]. Available online at. https://amsterdamsmartcity.com/themes/circular-city. (Accessed 14 May 2019).

Anpo, M., Fukuda, H., Endo, M., 2019. Plant Factory Using Artificial Light. Elsevier. ISBN: 978-0-12-813973-8.

Antikainen, M., Valkokari, K., 2016. A framework for sustainable business model innovation. Techn. Innov. Manag. Rev. 6, 5-12. Available online at: https:// timreview.ca/article/1000.

Antikainen, M., Aminoff, A., Paloheimo, H., Kettunen, O., 2017. Designing CBM experimentation - case study. ISPIM Innovation Forum, (March), 1-14. https:// doi.org/10.1016/j.surfcoat.2008.06.124. 
Augusto de Jesus Pacheco, D., et al., 2019. Overcoming barriers towards sustainable PSSs in small and medium-sized enterprises: state of the art and a novel decision matrix. J. Clean. Prod. 222, 903-921. Available online at: https://www. sciencedirect.com/science/article/pii/S0959652619301714.

Baines, T.S., Lightfoot, H.W., Evans, S., Neely, A., Greenough, R., Peppard, J., Roy, R., Shehab, E., Braganza, A., Tiwari, A., Alcock, J.R., Angus, J.P., Bastl, M., Cousens, A., Irving, P., Johnson, M., Kingston, J., Lockett, H., Martinez, V., Michele, P., Tranfield, D., Walton, I.M., Wilson, H., 2007. State-of-the-art in PSSs in proceedings of the institution of mechanical engineers. B J. Eng. Manuf. 221, 1543-1552. Available online at:,. https://doi.org/10.1243/09544054JEM858.

Baldassarre, B., Schepers, M., Bocken, N., Cuppen, E., Korevaar, G., Calabretta, G., 2019. Industrial symbiosis: towards a design process for eco-industrial clusters by integrating Circular Economy and Industrial Ecology perspectives. J. Clean. Prod. 216, 446-460. https://doi.org/10.1016/j.jclepro.2019.01.091. Available online at:

Beattie, V., Smith, S.J., 2013. Value creation and business models: refocusing the intellectual capital debate. Br. Account. Rev. 45, 243-254. https://doi.org/ 10.1016/j.bar.2013.06.001. Available online at:

Belz, F.M., Binder, J.K., 2017. Sustainable entrepreneurship: a convergent process model. Bus. Strateg. Environ. 26, 1-17. https://doi.org/10.1002/bse.1887. Available online at:

Bergset, L., 2017. Green start-up finance - where do particular challenges lie? Int. J. Environ. Behav. Res. 24, 451-575. https://doi.org/10.1108/IJEBR-11-2015-0260. Available online at:

Bergset, L., Fichter, K., 2015. Green start-ups - a new typology for sustainable entrepre-neurship and innovation research. J. Innov. Manag. 3, 118-144. https://doi.org/10.24840/2183-0606_003.003_0009. Available online at:

Berlin Business Location Center, 2017. Kreislaufwirtschaft in Berlin. Available online at. https://www.businesslocationcenter.de/imperia/md/blc/broschueren/ content/kreislaufwirtschaft_de.pdf.

Bernon, M., Tjahjono, B., Ripanti, E.F., 2017. Aligning retail reverse logistics practice with circular economy values: an exploratory framework. Prod. Plan. Control 29 (6), 483-497. https://doi.org/10.1080/09537287.2018.1449266. Available online at:

Besch, K., 2004. PSSs for office furniture: barriers and opportunities on the European market. J. Clean. Prod. 13, 1083-1094.

Blomsma, F., Brennan, G., 2017. The emergence of circular economy: a new framing around prolonging resource productivity. J. Ind. Ecol. 21 (3), 603-614. https:// doi.org/10.1111/jiec.12603. Available online at:

Bocken, et al., 2014. A literature and practice review to develop sustainable business model archetypes. J. Clean. Prod. 65, 42-56.

Bocken, et al., 2016. Product design and business model strategies for a circular economy. J. Ind. Prod. Eng. 33, 308-320. https://doi.org/10.1080/ 21681015.2016.1172124. Available online at:

Bocken, et al., 2017. The circular economy - exploring the introduction of the concept AmongS\&P 500 firm. J. Ind. Ecol. 21 (3), 487-490.

Boons, F., Lüdeke-Freund, F., 2013. Business models for sustainable innovation: state-of- the-art and steps towards a research agenda. J. Clean. Prod. 45, 9-19.

Borzaga, C., Defourny, J., 2001. The Emergence of Social Enterprise. Routledge, London \& New York.

Bourque, E., Dudek, G., 2004. Procedural texture matching and transformation. Comput. Graph. Forum, Eurogr. 23. Issue 3. Available online at: http://cim. mcgill.ca/mrl/pubs/ericb/eg2004.pdf.

Brennan, D., Tennant, M., Blomsma, F., 2015. Business and production solutions closing loops and the circular economy. In: Kopnina, H., Blewitt, J. (Eds.), Sustainability: Key Issues. Routledge, London, United Kingdom.

Brush, C.G., Vanderwerf, P.A., 1992. A comparison of methods and sources for obtaining estimates of new venture performance. J. Bus. Ventur. 7, 157-170. https://doi.org/10.1016/0883-9026(92)90010-O. Available online at:

Buzby, J.C., Hyman, J., 2012. Total and per capita value of food loss in the United States, 5 Food Policy 37, 561-570. Available online at: https://www. sciencedirect.com/science/article/pii/S0956053X18304562\#b0045.

Campanhola, C., Pandey, S., 2019. Sustainable Food and Agriculture - an Integrated Approach. Academic Press. https://doi.org/10.1016/C2016-0-01212-3. ISBN: 978-0-12-812134-4. Available at.

Canitez, F., 2019. Pathways to sustainable urban mobility in developing megacities: a socio-technical transition perspective. Technol. Forecast. Soc. Chang. 141, 319-329. Available online at: https://www.sciencedirect.com/science/article/ pii/S0040162518309880.

Carter, C.R., Ellram, L.M., 1998. Reverse logistics - a review of the literature and framework for future investigation. J. Bus. Logist. 19 (1), 85-102.

Carvalho, C.A.P., Vieira, M.M.F., Lopes, F.D., 1999. Contribuições da perspectiva institucional para análise das organizações in Anais do Encontro Nacional da Associação Nacional de Pós-Graduação e Pesquisa em Administração, Foz do Iguaçu, PR, Brasil. Available online at: http://www.anpad.org.br/admin/pdf/ enanpad1999-org-26.pdf.

Carvalho, A.D.P., et al., 2017. The role and contributions of sociological institutional theory to the socio-technical approach to innovation theory. RAI Rev. Adm. Inov. 14 (3), 250-259. https://doi.org/10.1016/j.rai.2017.02.001. Available online at:

Castellani, V., Sala, S., Mirabella, N., 2015. Beyond the throwaway society: a life cycle-based assessment of the environmental benefit of reuse. Integr. Environ. Assess. Manag. 11, 373-382. https://doi.org/10.1002/ieam.1614. Availanble online at:

Chertow, M.R., 2000. Industrial symbiosis: literature and taxonomy. Annu. Rev.

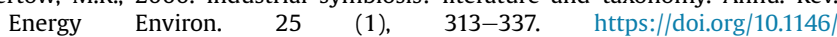

annurev.energy.25.1.313. Available online at:

Chesbrough, H., 2010. Business model innovation: opportunities and barriers. Long Range Plan. Bus. Models 43, 354-363. https://doi.org/10.1016/j.lrp.2009.07.010. Available online at:

Choi, D.Y., Gray, E.R., 2008. The venture development processes of "sustainable" entrepreneurs. Manag. Res. News 31, 558-569. https://doi.org/10.1108/ 01409170810892127. Available online at:

Christensen, C., 1997. The Innovator's Dilemma: when New Technologies Cause Great Firms to Fail. Harvard Business School Press, Boston, Mass.

Circle Economy, 2019. The Circularity Gap Report: an analysis of the circular state of the global economy. Available online at: https://docs.wixstatic.com/ugd/ ad6e59_ba1e4d16c64f44fa94fbd8708eae8e34.pdf.

Cohen, B., Winn, M.I., 2007. Market imperfections, opportunity and sustainable entrepreneurship. J. Bus. Ventur. 22, 29-49. https://doi.org/10.1016/j.jbusvent.2004.12.001. Available online at:

Colombelli, A., Quatraro, F., 2019. Green start-ups and local knowledge spillovers from clean and dirty technologies. Small Bus. Econ. 52 (4), 773-792. https:// doi.org/10.1007/s11187-017-9934-y. Available online at:

Copani, G., Behnam, S., 2018. Remanufacturing with upgrade PSS for new sustainable business models. CIRP J. Manuf. Sci. Technol. https://doi.org/10.1016 j.cirpj.2018.10.005, 2018, ISSN 1755-5817, available online at:, In press.

Davies, C., Lafortezza, R., 2019. Transitional path to the adoption of nature-based solutions in Land Use Policy. Available online at: https://doi.org/10.1016/j. landusepol.2018.09.020, 80, 406-409.

Dean, T.J., McMullen, J.S., 2007. Toward a theory of sustainable entrepreneurship: reducing environmental degradation through entrepreneurial action. J. Bus. Ventur. 22, 50-76. https://doi.org/10.1016/j.jbusvent.2005.09.003. Available online at:

Defourny, J., Nyssens, M., 2010. Conceptions of social enterprise and social entrepreneurship in Europe and the United States: convergences and divergences. J. Soc. Entrepren. 1, 32-53. https://doi.org/10.1080/19420670903442053. Available online at:

Despeisse, M., et al., 2017. Unlocking value for a circular economy through 3D printing: a research agenda. Technol. Forecast. Soc. Chang. 115, 75-84. https:/ doi.org/10.1016/j.techfore.2016.09.021. Available online at:

Diaz Lopez, F., Bastein, T., Tukker, A., 2019. Business model innovation for resourceefficiency, circularity and cleaner production: what 143 cases tell us. Ecol. Econ. 155, 20-35.

van Dijck, J., Poell, T., de Waal, M., 2018. The Platform Society - Public Values in a Connective World. Oxford University Press. ISBN: 0190889772.

Doherty, B., Haugh, H., Lyon, F., 2014. Social enterprises as hybrid organizations: a review and research agenda. Int. J. Manag. Rev. 16, 417-436. https://doi.org/ 10.1111/ijmr.12028. Available online at:

Domenech, T., et al., 2019. Mapping IS Development in Europe typologies of networks, characteristics, performance and contribution to the Circular Economy Resour. Conserv. Recycl. 141, 76-98. https://doi.org/10.1016/j.resconrec.2018.09.016. Available online at:

Ellen MacArthur Foundation, 2012. Towards the CE: economic and business rationale for an accelerated transition. Available online at: http://tinyurl.com/ pv7q714.

Ellen MacArthur Foundation, 2015. Growth within: a circular economy vision for a competitive Europe. Available online at: https://www. ellenmacarthurfoundation.org/assets/downloads/publications/ EllenMacArthurFoundation_Growth-Within_July15.pdf.

Ellen MacArthur Foundation, et al., 2019. Artificial intelligence and the circular economy - ai as a tool to accelerate the transition. Available online at: https:// www.ellenmacarthurfoundation.org/assets/downloads/Artificial-intelligenceand-the-circular-economy.pdf.

European Commission, 2008. Directive 2008/98/EC of the european parliament and of the council of 19 november 2008 on waste and repealing certain directives. Available at. http://eur-lex.europa.eu/legal-content/EN/TXT/PDF/?uri=CELEX 32008L0098\&from $=$ EN.

European Commission, 2015. Towards an EU Research and Innovation Policy Agenda for Nature-Based Solutions and Re-naturing Cities in Final Report of the Horizon 2020 Expert Group on "Nature-Based Solutions and Re-naturing Cities. European Commission, Brussels, Belgium.

European Commission, 2016. Closing the loop-an EU action plan for the CE. Brussels: European Commission. Available online at : http://eur-lex.europa.eu legal-content/EN/TXT/?uri=CELEX:52015DC0614.

European Commission, 2018. Horizon 2020 - work Programme 2018-2020 - 12 Climate action, environment, resource efficiency and raw materials. Available online at: http://ec.europa.eu/research/participants/data/ref/h2020/wp/20182020/main/h2020-wp1820-climate_en.pdf.

European Startup Initiative, 2017. Startup heatmap Europe. Available online at: https://www.startupheatmap.eu/analytics.

Faivre, N., Fritz, M., Freitas, T., de Boissezon, B., Vandewoestijne, S., 2017. NatureBased Solutions in the EU: innovating with nature to address social, economic and environmental challenges. Environ. Res. 159, 509-518. https://doi.org/ 10.1016/j.envres.2017.08.032. Available online at:

Farooque, M., Zhang, A., Huisingh, D., 2019. Circular supply chain management: a definition and structured literature review. J. Clean. Prod. 228, 882-900. https://doi.org/10.1016/j.jclepro.2019.04.303. Available online at:

Forum for the Future, 2016. The circular economy business model toolkit: a toolkit that helps businesses transition from the linear to the circular economy Available online at: https://www.forumforthefuture.org/project/circular- 
economy-business-model-toolkit/overview.

Foss, N., Saebi, T., 2016. Fifteen years of research on business model innovation: how far have we come, and where should we go? J. Manag. 43 (1). Available online at: https://doi.org/10.1177/0149206316675927.

Franco, M.A., 2017. Circular economy at the micro level: a dynamic view of incumbents' struggles and challenges in the textile industry. J. Clean. Prod. 168, 833-845. https://doi.org/10.1016/j.jclepro.2017.09.056. Available online at:

Frantzeskaki, N., 2019. Seven lessons for planning nature-based solutions in cities. Environ. Sci. Policy 93, 101-111.

Frishammar, J., Parida, V., 2019. Circular business model transformation: a roadmap for incumbent firms. Calif. Manag. Rev. 61, 5-29. https://doi.org/10.1177 0008125618811926. Available online at:

Fuenfschilling, L., Truffer, B., 2013. The structuration of socio-technical regimes conceptual foundations from institutional theory, 4 Res. Policy 43, 772-791.

Geels, F.W., 2005. Technological Transitions and System Innovations; A Coevolutionary and Socio-Technical Analysis. Edward Elgar, Cheltenham.

Geissdoerfer, M., Savaget, P., Bocken, N.M.P., Hultink, E.J., 2017. The Circular Economy - a new sustainability paradigm? J. Clean. Prod. 143, 757-768. https:/ doi.org/10.1016/j.jclepro.2016.12.048. Available online at :

Geissdoerfer, M., Vladimirova, D., Evans, S., 2018. Sustainable business model innovation: a review. J. Clean. Prod. 198, 401-416. https://doi.org/10.1016 j.jclepro.2018.06.240. Available online at:

Gemeente Rotterdam, 2016. Roadmap circular economy Rotterdam. Available online at. http://www.rotterdamclimateinitiative.nl/documents/2016/roadmapcircular-economy.pdf.

Geng, Y., Zhu, Q., Doberstein, B., Fujita, T., 2009. Implementing China's circular economy concept at the regional level: a review of progress in Dalian, China. Waste Manag. 29 (2), 996-1002. https://doi.org/10.1016/j.wasman.2008.06.036. Available online at:

Ghisellini, P., Cialani, C., Ulgiati, S., 2016. A review on CE: the expected transition to a balanced interplay of environmental and economic systems. J. Clean. Prod. 114, 11-32. https://doi.org/10.1016/j.jclepro.2015.09.007. Available online at:

Graedel, T.E., Allwood, J., Birat, J.P., Buchert, M., Hagelüken, C., Reck, B.K., et al., 2011. What do we know about metal recycling rates? J. Ind. Ecol. 15 (3), 355-366.

Haas, W., Kausmann, F., Wiedenhofer, D., Heinz, M., 2005. How circular is the global economy?: an assessment of material flows, waste production, and recycling in the European Union and the world in 2005. J. Ind. Ecol. 19 (5), 765-777. https:/ doi.org/10.1111/jiec.12244. Available online at:

Hall, J.K., Daneke, G.A., Lenox, M.J., 2010. Sustainable development and entrepreneurship: past contributions and future directions. J. Bus. Ventur. 25 (5), 439-448. https://doi.org/10.1016/j.jbusvent.2010.01.002. Available online at:

Hazen, B.T., Mollenkopf, D.A., Wang, Y., 2017. Remanufacturing for the circular economy: an examination of consumer switching behavior. Bus. Strateg. Environ. 26 (4), 451-464.

Hekkert, M.P., Suurs, R.A.A., Negro, S.O., Kuhlmann, S., Smits, R.E.H.M., 2007. Functions of innovation systems - a new approach for analysing technological change, 4 Technol. Forecast. Soc. Chang. 74, 413-432.

Henderson, R., Clark, K., 1990. Architectural innovation: the reconfiguration of existing product technologies and the failure of established firms. Adm. Sci. 35 (1), 9-30. Available online at: https://www.jstor.org/stable/2393549.

Heyes, G., Sharmina, M., Mendoza, J.M.F., Gallego Schmid, A., 2018. Developing and implementing circular economy business models in service-oriented technology companies. J. Clean. Prod. 177, 621-632. https://doi.org/10.1016/j.jclepro.2017.12.168. Available online at:

Hill, C.W.L., Rothaermel, F.T., 2003. The performance of incumbent firms in the face of radical technological innovation, 2 Acad. Manag. Rev. 28, 258-274. https:// doi.org/10.5465/amr.2003.9416161. Available online at:

Hockerts, K., Wüstenhagen, R., 2010. Greening Goliaths versus emerging Davids theorizing about the role of incumbents and new entrants in sustainable entrepreneurship. J. Bus. Ventur. Sustain. Dev. Entrepren. 25, 481-492. https:// doi.org/10.1016/j.jbusvent.2009.07.005. Available online at:

Hofnaegels, K., 2016. Das Tropicana-Kollektiv in smart magazine. Available online at. https://de.smart-magazine.com/bluecity010-rotterdam/.

Hruschka, D.J., Schwartz, D., St John, D.C., Picone-Decaro, E., Jenkins, R.A., Carey, J.W., 2004. Reliability in coding open-ended data: lessons learned from HIV behav ioral research. Field Methods 16, 307-331. https://doi.org/10.1177 1525822X04266540. Available online at:

Hsieh, H.-F., Shannon, S.E., 2005. Three approaches to qualitative content analysis. Qual. Health Res. 15, 1277-1288. https://doi.org/10.1177/1049732305276687. Available online at:

Hyde, K., Smith, A., Smith, M., Henningsson, S., 2001. The challenge of waste minimisation in the food and drink industry: a demonstration project in Eas Anglia, UK. J. Clean. Prod. 9, 57-64. https://doi.org/10.1016/S0959-6526(00) 00050-0. Available online at:

Jawahir, I.S., Dillon, O.W., Rouch, K.E., Joshi, K.J., Jaafar, I.H., 2006. Total life-Cycle considerations in product design for sustainability: a framework for comprehensive evaluation. In: At 10th International Research/Expert Conference Trends in the Development of Machinery and Associated Technology. University of Kentucky, pp. 11-15.

Jawahir, I.S., Rouch, K.E., Dillon, O.W., Holloway Jr., L., Hall, A., 2007. Design for sustainability (DFS): new challenges in developing and implementing a curriculum for next generation design and manufacturing engineers. Int. J. Eng. Educ. 23 (6), 1053-1064.

Jayal, A.D., Badurdeen, F., Dillon, O.W., Jawahir, I.S., 2010. Sustainable manufacturing: modeling and optimization challenges at the product, process and system levels. CIRP J. Manuf. Sci. Technol. 2 (3), 144-152. https://doi.org/ 10.1016/i.cirpj.2010.03.006. Available online at:

Jiang, W., Chai, H., Shao, J., Feng, T., 2018. Green entrepreneurial orientation for enhancingfirm performance: adynamic capability perspective. J. Clean. Prod. 198, 1311-1323. https://doi.org/10.1016/j.jclepro.2018.07.104. Available online

Johnson, M.W., 2010. Seizing the White Space. Business Model Innovation for Growth and Renewal. Harvard Business School Press, Boston, MA.

Kabisch, et al., 2016. Nature-based solutions to climate change mitigation and adaptation in urban areas: perspectives on indicators, knowledge gaps, barriers, and opportunities for action. Ecol. Soc. 21 (2) https://doi.org/10.5751/ES-08373210239. Page $39 \mathrm{f}$. Available online at:

Keskin, D., Diehl, J.C., Molenaar, N., 2013. Innovation process of new ventures driven by sustainability. J. Clean. Prod. Sustain. Innov. Bus. Models 45, 50-60. https:// doi.org/10.1016/j.jclepro.2012.05.012. Available online at:

King, A.M., Burgess, S.C., Ijomah, W., Mcmahon, C.A., 2006. Reducing waste: repair recondition, remanufacture or recycle? Sustain. Dev. 14, 257-267. https:// doi.org/10.1002/sd.271. Available online at:

Kirchherr, et al., 2017. Conceptualizing the CE: an analysis of 114 definitions in Resources. Conserv. Recycl. 127, 221-232. https://doi.org/10.1016/j.resconrec.2017.09.005. Available online at:

Kirchherr, Julian, Charles, Katrina, 2018. Enhancing the sample diversity of snowball samples: Recommendations from a research project on anti-dam movements in Southeast Asia. PLoS One 13 (8), e0201710.

Kirchherr, J., Piscicelli, L., Bour, R., Kostense-Smit, E., Muller, J., HuibrechtseTruijens, A., Hekkert, M., 2018. Barriers to the Circular Economy: Evidence From the European Union (EU) in Ecological Economis, vol. 150, pp. 264-272. Available online at: https://doi.org/10.1016/j.ecolecon.2018.04.028.

Kirchher, J., Piscicelli, L., 2019. Towards an Education for the Circular Economy (ECE): Five Teaching Principles and a Case Study in Resources Conservation and Recycling, vol. 150. Available online at: https://doi.org/10.1016/j.resconrec.2019. 104406.

Kirchherr, J., van Santen, R., 2019. Research on the circular economy: A critique of the field in Resources, Conservation and Recycling, vol.151. Available online at: https://doi.org/10.1016/j.resconrec.2019.104480.

Kirkpatrick, J., Davison, A., Harwood, A., 2013. How tree professionals perceive trees and conflicts about trees in Australia's urban forest. Landsc. Urban Plan. 119, 124-130. https://doi.org/10.1016/j.landurbplan.2013.07.009. Available online at:

Kirkwood, J., Walton, S., 2010. What motivates ecopreneurs to start businesses? Int. J. Entrep. Behav. Res. 16 (3), 204-228. https://doi.org/10.1108/ 13552551011042799. Available online at:

Klewitz, J., Hansen, E.G., 2014. Sustainability-oriented innovation of SMEs: a systematic review. J. Clean. Prod. 65, 57-75. https://doi.org/10.1016/j.jclepro.2013.07.017. Available online at:

Klyver, K., Terjesen, S., 2007. Entrepreneurial network composition: an analysis across venture development stage and gender. Women Manag. Rev. 22, 682-688. https://doi.org/10.1108/09649420710836344. Available online at:

Konietzko, J., Bocken, N., Hultink, E.J., 2019. Online Platforms and the Circular Economy. Innovation for Sustainability: Business Transformations towards a Better World. Palgrave Macmillan, Cham, pp. 435-450. Chapter: 23.

Krausmann, F., Gingrich, S., Eisenmenger, N., Erb, K.-H., Haberl, H., FischerKowalski, M., 2009. Growth in global materials use, GDP and population during the 20th century. Ecol. Econ. 68, 2696-2705. https://doi.org/10.1016/j.ecolecon.2009.05.007. Available online at:

Krauze, K. Wagner, I., 2019. From classical water-ecosystem theories to naturebased solutions - contextualizing nature-based solutions for sustainable city. Sci. Total Environ. 655, 697-706. https://doi.org/10.1016/j.scitotenv.2018.11.187. Available online at:

Krippendorff, K., 2013. Content Analysis. An Introduction to its Methodology, third ed. Sage Publications, California, CA.

Kronenberg, J., 2015. Why not to green a city? Institutional barriers to preserving urban ecosystem services. Ecosyst. Serv. 12, 218-227. https://doi.org/10.1016/ j.ecoser.2014.07.002. Available online at:

Kühl, C., Tjahjono, B., Bourlakis, M., Aktas, E., 2018. Implementation of circular economy principles in PSS operations. Procedia CIRP 71, 124-129. Available online at: https://www.sciencedirect.com/science/article/pii/ S2212827118304840.

Kyaw, T.Y., Ng, A.K., 2017. Smart aquaponics system for urban farming. Energy Procedia 143, 342-347. https://doi.org/10.1016/j.egypro.2017.12.694. Available online at:

Lafortezza, R., Sanesi, G., 2019. Nature-based solutions: settling the issue of sustainable urbanization. Environ. Res. 172, 394-398. https://doi.org/10.1016/ j.envres.2018.12.063. Available online at:

Lambert, D.M., Stock, J.R., 1982. Strategic Physical Distribution Management. RD: Irwin, Homewood, IL.

Lenox, M., York, J.G., 2011. Environmental Entrepreneurship. Oxford University Press. https://doi.org/10.1093/oxfordhb/9780199584451.003.0004.

Lewandowski, M., 2016. Designing the business models for circular economy towards the conceptual framework. Sustainability 8 (1). https://doi.org/ 10.3390/su8010043. Available online at:

Lieder, M., Rashid, A., 2016. Towards circular economy implementation: a comprehensive review in context of manufacturing industry. J. Clean. Prod. 115, 36-51. https://doi.org/10.1016/j.jclepro.2015.12.042. Available online at:

Linder, M., Williander, M., 2017. CBM innovation: inherent uncertainties. Bus. Strateg. Environ. 26 (2), 182-196. https://doi.org/10.1002/bse.1906. Available 
online at:

Lohr, V.I., Pearson-Mims, C., Tarnai, J., Dillman, D., 2004. How urban residents rate and rank the benefits and problems associated with trees in cities. J. Arboric. 30, 28-35. Available online at: https://opinion.wsu.edu/tarnai/paper/jarbhr.pdf.

London Waste and Recycling Board, 2017. London's circular economy route map [WWW document]. Available online at: https://www.lwarb.gov.uk/wp-content/ uploads/2015/04/LWARB-London\%E2\%80\%99s-CE-route-map_16.6.17a_ singlepages_sml.pdf. (Accessed 14 May 2019).

Lüdeke-Freund, F., Dembek, K., 2017. Sustainable business model research and practice: emerging field or passing fancy? J. Clean. Prod. 168, 1668-1678. https://doi.org/10.1016/j.jclepro.2017.08.093. Available online at:

Lüdeke-Freund, F., Carroux, S., Joyce, A., Massa, L., Breuer, H., 2018. The sustainable business model pattern taxonomy-45 patterns to support sustainabilityoriented business model innovation. Sustain. Prod. Consum. 15, 145-162. https://doi.org/10.1016/j.spc.2018.06.004. Available online at:

Luger, M., Koo, J., 2005. Defining and tracking business start-ups, 1 Small Bus. Econ. $24,17-28$.

Luiten, H., Knot, M., van der Horst, T., 2001. Sustainable PSSs: the Kathalys Method at Proceedings Second International Symposium on Environmentally Conscious Design and Inverse Manufacturing, pp. 190-197.

Ma, S., Wen, Zong-guo, Chen, J., Wen, Zhi-chao, 2014. Mode of circular economy in China's iron and steel industry: a case study in Wu'an city. J. Clean. Prod. 64, 505-512. https://doi.org/10.1016/j.jclepro.2013.10.008. Available online at:

Maes, J., Jacobs, S., 2017. Nature-based solutions for europe's sustainable development. Conserv. Lett. 10, 121-124. https://doi.org/10.1111/conl.12216. Available online at:

Manzini, E., Vezzoli, C., Clark, G., 2001. PSSs: using an existing concept as a new approach to sustainability. J. Des. Res. 1 (2) https://doi.org/10.1504/ JDR.2001.009811. Available online at:

Martin-Rios, C., et al., 2018. Food waste management innovations in the foodservice industry. Waste Manag. 79, 196-206. https://doi.org/10.1016/j.wasman.2018.07.033. Available online at:

Massa, L., Tucci, C., 2014. Business Model Innovation in the Oxford Handbook of Innovation Management. Oxford Press. https://doi.org/10.1093/oxfordhb\% 2F9780199694945.013.002. Available online at:

McDonough, W., Braungart, M., 2002. Cradle to Cradle: Remaking the Way We Make Things. North Point, New York.

McIntyre, K., Ortiz, J.A., 2016. Multinational corporations and the circular economy: how hewlett packard scales innovation and technology in its global supply chain. In: Clift, R., Druckman, A. (Eds.), Taking Stock of Industrial Ecology. Springer International Publishing, Cham, pp. 317-330. https://doi.org/10.1007/ 978-3-319-20571-7_17. Available online at:

Mont, O., Tukker, A., 2006. Product-Service Systems: reviewing achievements and refining the research agenda. J. Clean. Prod. 14 (17), 1452-1454. https://doi.org/ 10.1016/j.jclepro.2006.01.017. Available online at:

Moreno, M., De los Rios, C., Rowe, Z., Charnley, F., 2016. A conceptual framework for circular design. Sustainability 8 (9), 1-15. https://doi.org/10.3390/su8090937. Available online at:

Mortensen, L., Kørnøv, L., 2019. Critical factors for IS emergence process. J. Clean. Prod. 212, 56-69. https://doi.org/10.1016/j.jclepro.2018.11.222. Available online at:

Murphy, P., 1986. A preliminary study of transportation and warehousing aspects of reverse distribution, 4 Transp. J. 25, 12-21. Available online at: https://www. jstor.org/stable/20712872.

Murphy, P.R., Poist, R.F., 1988. Management of logistical retromovements: an empirical analysis of literature suggestions. J. Transp. Res. Forum 29 (1). HS-040 801.

Murray, A., Skene, K., Haynes, K., 2017. The circular economy: an interdisciplinary exploration of the concept and application in a global context. J. Bus. Ethics 140, 369-380. Available online at: https://link.springer.com/article/10.1007/s10551015-2693-2.

Neely, A., 2008. Exploring the financial consequences of the servitization of manufacturing, 2 Oper. Manag. Res. 1, 103-118. https://doi.org/10.1007/s12063009-0015-5. Available online at:

Neuendorf, K.A., 2016. The Content Analysis Guidebook. SAGE.

Nhemachena, C., Murimbika, M., 2018. Motivations of sustainable entrepreneurship and their impact of enterprise performance in Gauteng Province, South Africa. Bus. Strat. Dev. 1, 115-127. https://doi.org/10.1002/bsd2.16. Available online at :

Niero, et al., 2017. Combining eco-efficiency and eco-effectiveness for continuous loop beverage packaging systems. J. Ind. Ecol. 21 (3), 742-753. https://doi.org/ 10.1111/jiec.12554. Available online at:

Osterwalder, A., Pigneur, Y., Tucci, C.L., 2005. Clarifying business models: origins, present, and future of the concept. Communications of the association for information systems 16. Available online at: https://doi.org/10.17705/1CAIS. 01601.

Osterwalder, A., Pigneur, Y., Clark, T., 2010. Business Model Generation: a Handbook for Visionaries, Game Changers, and Challengers. Wiley, Hoboken, NJ.

Pacheco, D.F., Dean, T.J., Payne, D.S., 2010. Escaping the green prison: entrepreneurship and the creation of opportunities for sustainable development. J. Bus. Vent. Sustain. Dev. Entrepren.. 25, 464-480. https://doi.org/10.1016/j.jbusvent.2009.07.006. Available online at:

Parrish, B.D., 2010. Sustainability-driven entrepreneurship: principles of organization design. J. Bus. Vent. Sustain. Dev. Entrepren. 25, 510-523. https://doi.org/ 10.1016/j.jbusvent.2009.05.005. Available online at:

Paunescu, C., Raluca Badea, M., 2014. Examining the social capital content and structure in the pre-start-up planning. Procedia Econ. Finance 15, 560-568. https://doi.org/10.1016/S2212-5671(14)00510-3. Available online at:

Peng, B., Tu, Y., Wei, G., 2018. Governance of electronic waste recycling based on social capital embeddedness theory. J. Clean. Prod. 187, 29-36. https://doi.org/ 10.1016/j.jclepro.2018.02.26. Available online at:

Pereira Pesoa, M.V., Jauregui Becker, J.M., 2017. Overcoming the product-service model adoption obstacles. Procedia CIRP 64, 163-168. https://doi.org/10.1016/ j.procir.2017.03.062. Available online at:

Pieroni, M.P.P., McAloone, T.C., Pigosso, D.C.A., 2019. Business model innovation for circular economy and sustainability: a review of approaches. J. Clean. Prod. 215, 198-216. https://doi.org/10.1016/j.jclepro.2019.01.036. Available online at:

Pinkse, J., Groot, K., 2015. Sustainable entrepreneurship and corporate political activity: overcoming market barriers in the clean energy sector. Entrep. Theory Pract. 39, 633-654. https://doi.org/10.1111/etap.12055. Available online at:

Planko, J., Cramer, J., Chappin, M., Hekkert, M., 2016. Strategic collective system building to commercialize sustainability innovations. J. Clean. Prod. 112, $2328-2341$.

Potting, J., Hekkert, M., Worrell, E., Hanemaaijer, A., 2017. Circular Economy: Measuring Innovation in the Product Chain in Policy Report for PBL Netherlands Environmental Assessment Agency.

PRC, 2008. Circular economy promotion law of the people's Republic of China Available at. https://ppp.worldbank.org/public-private-partnership/sites/ppp. worldbank.org/files/documents/China_CircularEconomyLawEnglish.pdf.

Prosman, E.J., Wæhrens, B.V., Liotta, G., 2017. Closing global material loops: initial insights into firm-level challenges. J. Ind. Ecol. 21 (3), 641-650. https://doi.org/ 10.1111/jiec.12535. Available online at:

Rabideau, M.M., Wong, K., Gordon, E.S., Ryan, L., 2016. Genetic counselors in Startup companies: redefining the genetic counselor role. J. Gen. Couns. 25, 649-657. https://doi.org/10.1007/s10897-015-9923-8. Available online at:

Ramanathan, R., 2011. An empirical analysis on the influence of risk on relationships between handling of product returns and customer loyalty in E-commerce. Int J. Prod. Econ. 130 (2), 255-261. https://doi.org/10.1016/j.ijpe.2011.01.005. Available online at:

Ranta, V., Aarikka-Stenroos, L., Mäkinen, S.J., 2018. Creating value in the circular economy: a structured multiple-case analysis of business models. J. Clean. Prod. 201, 988-1000. https://doi.org/10.1016/j.jclepro.2018.08.072. Available online at:

Ravi, V., Shankar, R., Tiwari, M.K., 2005. Analyzing alternatives in reverse logistics for end-of-life computers: ANP and balanced scorecard approach. Comput. Ind. Eng. 48 (2), 327-356. https://doi.org/10.1016/j.cie.2005.01.017. Available online at:

Reike, D., Vermeulen, W.J.V., Witjes, S., 2018. The circular economy: new or refurbished as CE 3.0? - exploring controversies in the conceptualization of the circular economy through a focus on history and resource value retention options. Resour. Conserv. Recycl. Sustain. Resour. Manag. Circ. Econ. 135, 246-264. https://doi.org/10.1016/j.resconrec.2017.08.027. Available online at:

Ren, S., Zhang, Y., Liu, Y., Sakao, T., Huisingh, D., Almeida, C.M.V.B., 2019 A comprehensive review of big data analytics throughout product lifecycle to support sustainable smart manufacturing: a framework, challenges and future research directions. J. Clean. Prod. 210, 1343-1365. https://doi.org/10.1016/ j.jclepro.2018.11.025. Available online at:

van Renswoude, K., ten Wolde, A., Joustra, D.J., 2015. CBMs - Part 1: an Introduction to IMSA's CBM Scan. IMSA Amsterdam. April 2015.

Ribeiro, I., Sobral, P., Pecas, P., Henriques, E., 2018. A sustainable business model to fight food waste. J. Clean. Prod. 177, 262-275.

Richardson, J., 2008. The business model: an integrative framework for strategy execution. Strateg. Chang. 17, 133-144. https://doi.org/10.1002/jsc.821. Available online at:

De los Rios, I.C., Charnley, F.J.S., 2017. Skills and capabilities for a sustainable and circular economy: the changing role of design. J. Clean. Prod. Multinatl. Enterp. Strat. Dyn. Clim. Chang.: Driv. Barriers Impacts Necess. Organ. Chang. 160, 109-122. https://doi.org/10.1016/j.jclepro.2016.10.130. Available online at:

Ritter, M., Schanz, H., 2019. The sharing economy: a comprehensive business model framework. J. Clean. Prod. 213, 320-331. https://doi.org/10.1016/j.jclepro.2018.12.154. Available online at:

Rizos, V., Behrens, A., van der Gaast, W., Hofman, E., Ioannou, A., Kafyeke, T., Flamos, A., Rinaldi, R., Papadelis, S., Hirschnitz-Garbers, M., Topi, C., 2016. Implementation of circular economy business models by small and mediumsized enterprises (SMEs): barriers and enablers, 11 Sustainability 8, 1212 https://doi.org/10.3390/su8111212.

Robehmed, N., 2013. What is a Startup? https://www.forbes.com/sites/ natalierobehmed/2013/12/16/what-is-a-startup/\#53c3b5bd4044.

Rogers, D.S., Tibben-Lembke, R.S., 1999. Going Backwards: Reverse Logistics Trends and Practices, vol. 2. Reverse Logistics Executive Council, Pittsburgh, PA.

Saffer, A.J., 2019. Fostering social capital in an international multi-stakeholder issue network, 2 Public Relat. Rev. 45, 282-296. https://doi.org/10.1016/ j.pubrev.2019.02.004. Available online at:

Schallehn, H., Seuring, S., Strähle, J., Freise, M., 2019. Customer experience creation for after-use products: a product-service systems-based review. J. Clean. Prod. 210, 929-944. https://doi.org/10.1016/j.jclepro.2018.10.292. Available online at:

Schaltegger, S., 2002. A framework for ecopreneurship: leading bioneers and environmental managers to ecopreneurship. Greener Manag. J. 38, 45-58. Available online at: https://papers.ssrn.com/sol3/papers.cfm?abstract_ id $=1512312$.

Schaltegger, S., Wagner, M., 2011. Sustainable entrepreneurship and sustainability 
innovation: categories and interactions. Bus. Strateg. Environ. 20, 222-237. https://doi.org/10.1002/bse.682. Available online at:

Schaltegger, S., Lüdeke-Freund, F., Hansen, E.G., 2016. Business models for sustainability: a Co-evolutionary analysis of sustainable entrepreneurship, innovation, and transformation. Organ. Environ. 29, 264-289. https://doi.org/ 10.1177/1086026616633272. Available online at:

Schiederig, T., Tietze, F., Herstatt, C., 2012. Green innovation in technology and innovation management - an exploratory literature review. R D Manag. 42, 180-192. https://doi.org/10.1111/j.1467-9310.2011.00672.x. Available online at:

Seuring, S., Müller, M., 2008. From a literature review to a conceptual framework for sustainable supply chain management. J. Clean. Prod. 16 (15), 1699-1710.

Shepherd, D.A., Patzelt, H., 2011. The new field of sustainable entrepreneurship: studying entrepreneurial action linking "what is to Be sustained" with "what is to Be developed. Entrep. Theory Pract. 35, 137-163. https://doi.org/10.1111/ j.1540-6520.2010.00426.x. Available online at:

Sihvonen, S., Ritola, T., 2015. Conceptualizing ReX for aggregating end-of-life strategies in product development. Proc. CIRP 29, 639-644. Available at: http:// linkinghub.elsevier.com/retrieve/pii/S2212827115000293.

Spring, M., Araujo, L., 2017. Product biographies in servitization and the circular economy. Ind. Mark. Manag. 60, 126-137. https://doi.org/10.1016/j.indmarman.2016.07.001. Available online at:

Stahel, W.R., 2010. The Performance Economy. Palgrave Macmillan Hampshire Hampshire UK.

Stewart, R., Niero, M., 2018. Circular economy in corporate sustainability strategies: a review of corporate sustainability reports in the fast-moving consumer goods sector. Bus. Strateg. Environ. 27 (7), 1005-1022. https://doi.org/10.1002 bse.2048. Available online at:

Stubbs, W., Cocklin, C., 2008. Conceptualizing a "sustainability business model Organ. Environ. 21, 103-127. https://doi.org/10.1177/1086026608318042. Available online at:

Thi, N., Biswarup, S., Chen, C.C., Gopalakrishnan, K., Lin, C.Y., 2014. Food waste to bioenergy via anaerobic processes. Energy Procedia 61, 307-312. https:// doi.org/10.1016/j.egypro.2014.11.1113. Available online at:

Thompson, N., Kiefer, K., York, J.G., 2011. Distinctions not dichotomies: exploring social, sustainable, and environmental entrepreneurship. In: Social and Sustainable Entrepreneurship. Emerald Group Publishing Limited, Bingley, pp. 201-229. https://doi.org/10.1108/S1074-7540(2011)0000013012.

Thompson, N.A., Herrmann, A.M., Hekkert, M.P., 2015. How sustainable entrepreneurs engage in institutional change: insights from biomass torrefaction in The Netherlands. J. Clean. Prod. Bridg. Sustain. Future: Join. Environ. Manag. Sustain. Univ. (EMSU) Eur. Roundtable Sustain. Consum. Prod. (ERSCP) Conf. 106, 608-618. https://doi.org/10.1016/j.jclepro.2014.08.011. Available online at:

Tukker, A., 2004. Eight types of product-service system: eight ways to sustainability? Experiences from SusProNet. Bus. Strateg. Environ. 13, 246-260. https://doi.org/10.1002/bse.414. Available online at:

Tukker, A., 2015. Product services for a resource-efficient and circular economy - a review. J. Clean. Prod. 97, 76-91. https://doi.org/10.1016/j.jclepro.2013.11.049. Available online at:

Tukker, A., Tischner, U., 2006. Product-services as a research field: past, present and future. Reflections from a decade of research. J. Clean. Prod. Prod. Serv. Syst. Rev. Achiev. Refin. Res. Agenda 14, 1552-1556. https://doi.org/10.1016 j.jclepro.2006.01.022. Available online at:

Tunn, V., Fokker, R., Luijkx, K., de Jong, S., Schoormans, J., 2019. Making ours mine: increasing consumer acceptanceof access-based PSS through temporary product customisation. Sustainability 11 (1), 274. https://doi.org/10.3390/ su11010274. Available online at:

Ünal, E., Shao, J., 2019. A taxonomy of circular economy implementation strategies for manufacturing firms: analysis of 391 cradle-to-cradle products. J. Clean. Prod. 212, 754-765. https://doi.org/10.1016/j.jclepro.2018.11.291. Available online at:

Urbinati, A., Chiaroni, D., Chiesa, V., 2017. Towards a new taxonomy of circular economy business models. J. Clean. Prod. 168, 487-498. https://doi.org/10.1016/ j.jclepro.2017.09.047. Available online at:

Veleva, V., Bodkin, G., 2018. Corporate-entrepreneur collaborations to advance a circular economy. J. Clean. Prod. 188, 20-37. https://doi.org/10.1016/j.jclepro.2018.03.196. Available online at:

Vezzoli, C., Ceschin, F., Diehl, J.C., Kohtala, C., 2015. New design challenges to widely implement 'sustainable product-service systems. J. Clean. Prod. 97, 1-12. https://doi.org/10.1016/j.jclepro.2015.02.061. Available online at:

Vujcic, M., Tomicevic-Dubljevic, J., Grbic, M., Lecic-Tosevski, D., Vukovic, O., Toskovic, O., 2017. Nature based solution for improving mental health and wellbeing in urban areas. Environ. Res. 158, 385-392. https://doi.org/10.1016/ j.envres.2017.06.030. Available online at:

Wastling, T., Charnley, F., Moreno, M., 2018. Design for circular behaviour: considering users in a circular economy, 6 Sustainability 10, 1743. https://doi.org/ 10.3390/su10061743. Available online at:

Whalen, K., 2017. Classifying circular business models: a practice-based review. In: Conference paper at PLATE: Product Lifetimes And The Environment, Delft, The Netherlands.

Williams, A., 2007. Product service systems in the automobile industry: contribution to system innovation? J. Clean. Prod. Automob. Ind. Sustain. 15, 1093-1103. https://doi.org/10.1016/j.jclepro.2006.05.034. Available online at:

Worrel, E., Reuter, M., 2014. Handbook of Recycling: State-Of-The-Art for Practitioners, Analysts, and Scientists. ISBN: 978-0123965066, Published by Newnes.

Yan, J., Wu, N., 2011. Technology supporting system of circular economy of mining cities at 2011 Asia-Pacific Power and Energy Engineering Conference. IEEE, Pages 1-5. Available at: http://ieeexplore.ieee.org/document/5749062/.

Yang, M., Evans, S., 2019. PSS business model archetypes and sustainability. J. Clean. Prod. 220, 1156-1166. Available online at: https://www.sciencedirect.com/ science/article/pii/S0959652619304524.

York, J.G., Venkataraman, S., 2010. The entrepreneur-environment nexus: uncertainty, innovation, and allocation. J. Bus. Vent. Sustain. Dev. Entrepren. 25 449-463. https://doi.org/10.1016/j.jbusvent.2009.07.007. Available online at:

Young, C.W., Russell, S.V., Robinson, C.A., Chintakayala, P.K., 2018. Sustainable retailing - influencing consumer behaviour on food waste. Bus. Strateg. Environ. 27 (1), 1-15. https://doi.org/10.1002/bse.1966. Available online at:

Zahra, S.A., Ireland, R.D., Hitt, M.A., 2000. International expansion by new venture firms: international diversity, mode of market entry, technological learning and performance. Acad. Manag. J. 43, 925-950. https://doi.org/10.5465/1556420. Available online at:

Zucchella, A., Urban, S., 2019. Circular Entrepreneurship. Palgrave Macmillan, Cham, Switzerland. https://doi.org/10.1007/978-3-030-18999-0. Available online at: 